\title{
An Overview of Existing Wind Energy Ordinances
}

\section{Technical Report} NREL/TP-500-44439

December 2008

F. Oteri

Contract No. DE-AC36-99-G010337 r
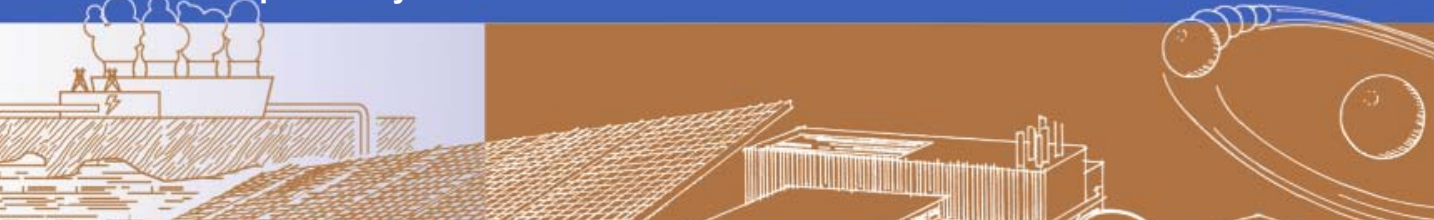


\section{An Overview of Existing Wind Energy Ordinances}

\section{F. Oteri}

Prepared under Task No. WER9.8503

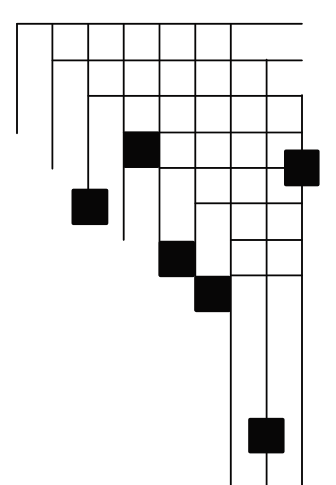

National Renewable Energy Laboratory

1617 Cole Boulevard, Golden, Colorado 80401-3393

303-275-3000 • www.nrel.gov

Operated for the U.S. Department of Energy

Office of Energy Efficiency and Renewable Energy

by Midwest Research Institute - Battelle

Contract No. DE-AC36-99-G010337 


\section{NOTICE}

This report was prepared as an account of work sponsored by an agency of the United States government. Neither the United States government nor any agency thereof, nor any of their employees, makes any warranty, express or implied, or assumes any legal liability or responsibility for the accuracy, completeness, or usefulness of any information, apparatus, product, or process disclosed, or represents that its use would not infringe privately owned rights. Reference herein to any specific commercial product, process, or service by trade name, trademark, manufacturer, or otherwise does not necessarily constitute or imply its endorsement, recommendation, or favoring by the United States government or any agency thereof. The views and opinions of authors expressed herein do not necessarily state or reflect those of the United States government or any agency thereof.

Available electronically at http://www.osti.gov/bridge

Available for a processing fee to U.S. Department of Energy and its contractors, in paper, from:

U.S. Department of Energy

Office of Scientific and Technical Information

P.O. Box 62

Oak Ridge, TN 37831-0062

phone: 865.576 .8401

fax: 865.576 .5728

email: mailto:reports@adonis.osti.gov

Available for sale to the public, in paper, from:

U.S. Department of Commerce

National Technical Information Service

5285 Port Royal Road

Springfield, VA 22161

phone: 800.553 .6847

fax: 703.605.6900

email: orders@ntis.fedworld.gov

online ordering: http://www.ntis.gov/ordering.htm 


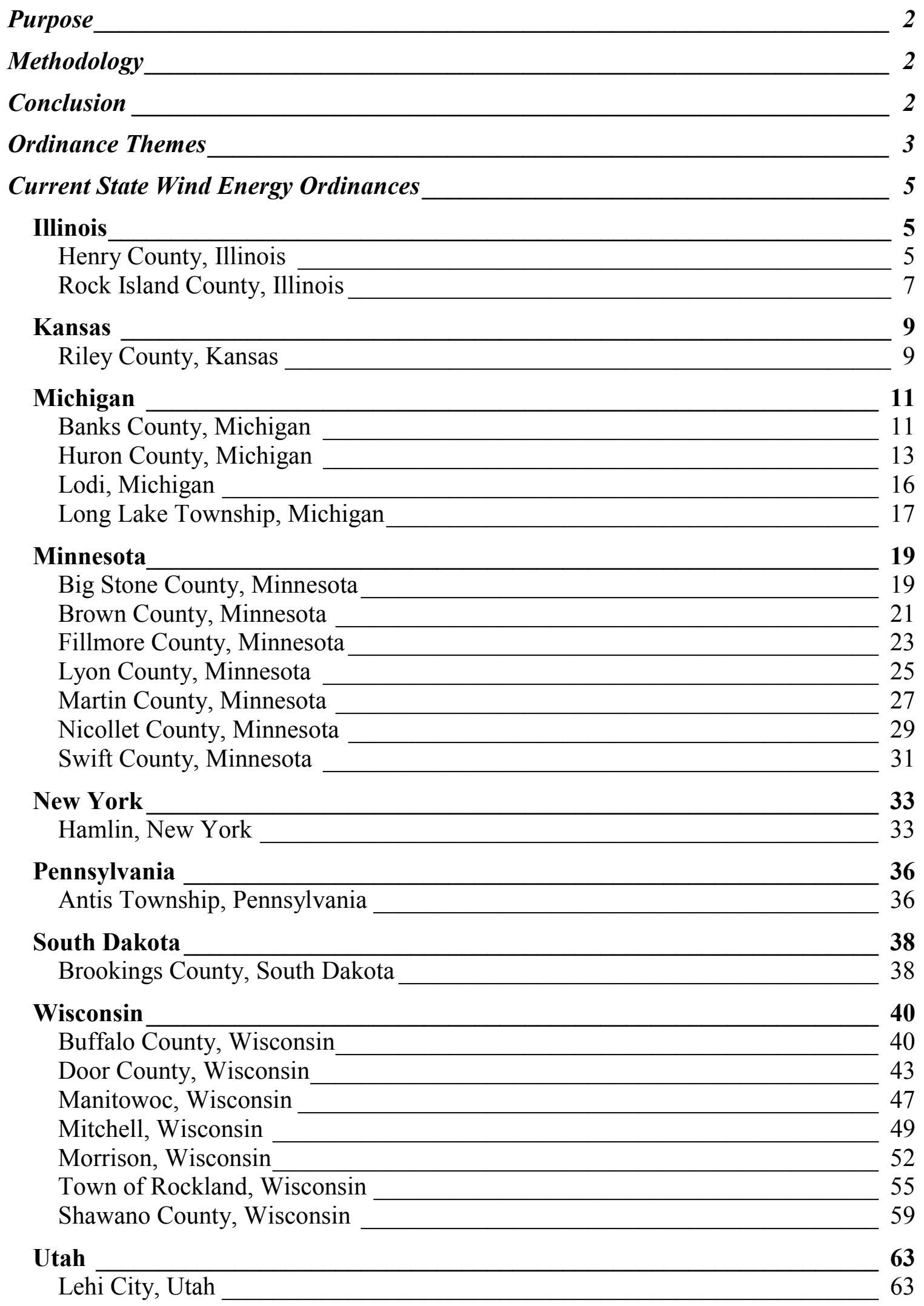




\section{Purpose}

Due to increased energy demand in the United States, rural communities with limited or no experience with wind energy now have the opportunity to become involved in this industry. Communities with good wind resources may be approached by entities with plans to develop the resource.

Although these opportunities can create new revenue in the form of construction jobs and land lease payments, they also create a new responsibility on the part of local governments to ensure that ordinances will be established to aid the development of safe facilities that will be embraced by the community.

The purpose of this report is to educate and engage state and local governments, as well as policymakers, about existing large wind energy ordinances. These groups will have a collection of examples to utilize when they attempt to draft a new large wind energy ordinance in a town or county without existing ordinances.

\section{Methodology}

A combination of Internet-based newspaper research and Internet research utilizing multiple search engines was utilized to identify the existing large wind energy ordinances.

The first step in the research was to compile a list of towns with existing ordinances. The next step was to find the official Web sites for the local governments and to verify through those sites that the ordinances did in fact exist and that they were final, approved ordinances as opposed to draft ordinances waiting for approval.

All information presented in this report is derived from official county or town Web sites.

\section{Conclusion}

Although wind energy ordinances currently exist in rural communities throughout the country, many communities have no regulations in place.

The specific details vary among the existing ordinances, but similar themes are addressed in many of them. 


\section{Ordinance Themes}

The following themes are typically included in ordinances regulating the development of commercial Wind Energy Conversion Systems (WECS). This list is provided to help towns or counties develop ordinances regulating utility-scale WECS.

\section{Access}

By defining access standards, towns/counties can ensure safety by limiting direct contact to the interior of the wind turbine tower, electrical equipment, and any climbing apparatus.

\section{Appearance, Color, and Finish}

By defining the appearance, color, and finish of turbines in WECS, local governments can limit aesthetic displeasure and ensure design uniformity.

\section{Clearance}

Normally measured from the lowest point of the arc created by rotating blades to the ground, a defined clearance height aids in addressing safety concerns.

\section{Electrical}

In order to ensure normal land usage, electrical standards may be put in place. These standards define whether electrical wires must be buried or if and when they are allowed overhead.

\section{Equipment}

Equipment standards typically further define the electrical standards by ensuring that any electrical equipment associated with a wind energy system is located in a specified area, usually under the swept area of the blade assembly.

\section{Height}

Height is usually measured from the base of the tower to the tip of the blade at its highest point. General town/county zoning ordinances often already define height allowances. An exception to allow greater heights for WECS may be necessary. The ordinance regulating the development of WECS should define this height.

\section{Lighting}

Lighting must comply with minimum Federal Aviation Administration regulations but can also be regulated to ensure minimal impact on neighboring properties.

\section{Noise Standards}

Noise standards create a standard maximum level of allowed noise due to the operation of WECS. These standards often include a defined method of measuring noise level.

\section{Permits}

The permitting process is utilized so local governments can review and allow for wind energy developments. Permits are usually granted in accordance to the provisions of the ordinance regulating the development of WECS. 


\section{Restoration Requirements}

Restoration requirements ensure that restoration standards are defined to the extent desired by the local government and community, typically to the level of restoring the area(s) where the wind turbines are located to their original condition at the end of the project life or facility abandonment. Restoration requirements sometimes include the posting of a performance bond or other financial instrument to ensure the disposal of WECS.

\section{Set Backs}

These standards are defined to create space between areas of concern and the WECS. Common areas of concern include property lines, inhabited structures, public roads, as well as communication and electrical lines.

\section{Shadow Flicker}

Shadow flicker is addressed within ordinances regulating the development of commercial WECS to prevent, mitigate, and eliminate shadow flicker on any roadway or any occupied structure on a non-participating property. (Shadow flicker is the term used to describe shadows on the ground and surrounding structures that may emanate from the rotating blades of a wind turbine.)

\section{Signage}

Defining specific sign standards ensures that WECS will not be used to advertise or promote any product or service. It also can guarantee the proper placement of warning signs and the identification of the owner and/or manufacturer.

\section{Signal Interference Standards}

Signal interference standards ensure that the construction and operation of WECS will not interfere with television, microwave, navigational, or radio reception in any neighboring areas.

\section{Spacing and Density}

Spacing and density standards address aesthetic concerns and safety issues by ensuring that individual wind turbines will not be sited so closely as to create a cluster.

\section{Zoning Areas}

Zoning area standards limit wind energy development to certain parts of the town/county where the overall impact will be minimal or in some cases to where the wind resource is best. 


\section{Current State Wind Energy Ordinances}

\section{Illinois}

Henry County, Illinois

\begin{tabular}{|c|c|}
\hline $\begin{array}{l}\text { Zoning Areas } \\
\text { Where Turbines are } \\
\text { Allowed }\end{array}$ & $\begin{array}{l}\text { 1) May be located in areas zoned AG1 Agriculture or M-1 } \\
\text { Manufacturing with special use and building permits } \\
\text { 2) Shall be located } 1000 \text { feet or more from an occupied structure on an } \\
\text { adjoining property and } 1.1 \text { times total tower height or more from an } \\
\text { occupied structure on subject property, measured from wind tower base }\end{array}$ \\
\hline Set Backs & $\begin{array}{l}\text { 1) } 1.1 \text { times total tower height from any and all public/private right-of- } \\
\text { way lines (measured from the wind tower base, unless a variance is } \\
\text { approved by the board) } \\
\text { 2) } 100 \text { feet from all other property lines (measured from the tip of the } \\
\text { blade when located parallel with the ground), unless a variance is } \\
\text { approved by the board }\end{array}$ \\
\hline $\begin{array}{l}\text { Spacing and } \\
\text { Density }\end{array}$ & $\begin{array}{l}\text { A wind energy system shall be separated from any other wind energy } \\
\text { system by a minimum of } 200 \text { feet (measured from the tips of the blades } \\
\text { when the blades are parallel with the ground). }\end{array}$ \\
\hline Height & Total height shall be 500 feet or less \\
\hline Clearance & $\begin{array}{l}\text { The vertical distance from ground level to the tip of a wind turbine } \\
\text { blade when the blade is at its lowest point must be at least } 25 \text { feet. }\end{array}$ \\
\hline Access & $\begin{array}{l}\text { Any wind tower located in a wind energy system, including any } \\
\text { climbing aids, shall be secured against unauthorized access by means of } \\
\text { a locked barrier or security fence. }\end{array}$ \\
\hline Electrical Wires & $\begin{array}{l}\text { All electrical wires associated with a wind energy system, other than } \\
\text { wires necessary to connect the wind turbine to its base and to overhead } \\
\text { collection lines, shall be located underground unless a variance is } \\
\text { approved by the board. }\end{array}$ \\
\hline Lighting & $\begin{array}{l}\text { As required by the Federal Aviation Administration. Required lighting } \\
\text { must comply with Federal Aviation Administration minimum } \\
\text { requirements and, whenever possible, be at the lowest intensity allowed } \\
\text { using red lights at night. If more than one lighting alternative is } \\
\text { available, the alternative that causes the least visual disturbance must be } \\
\text { used. }\end{array}$ \\
\hline Equipment & $\begin{array}{l}\text { Unless located underground, any electrical equipment associated with a } \\
\text { wind energy system shall be located under the sweep area of a blade } \\
\text { assembly unless the board approves a variance. }\end{array}$ \\
\hline $\begin{array}{l}\text { Appearance, Color, } \\
\text { and Finish }\end{array}$ & $\begin{array}{l}\text { The exterior of any visible components of a wind energy system must } \\
\text { be a non-reflective, neutral color. Wind towers and turbines in an } \\
\text { established wind farm system that are located within } 1,000 \text { feet of each } \\
\text { other must be of uniform design, including tower type, color, number of } \\
\text { blades, and direction of blade rotation unless a variance is approved by } \\
\text { the board. }\end{array}$ \\
\hline Signs & $\begin{array}{l}\text { No wind turbine, tower building, or other structure associated with a } \\
\text { wind energy system may be used to advertise or promote any product or } \\
\text { service. No word or graphic representation, other than appropriate }\end{array}$ \\
\hline
\end{tabular}




\begin{tabular}{|c|c|}
\hline & $\begin{array}{l}\text { warning signs and owner identification, may be placed on a wind } \\
\text { turbine, tower, building, or other structure associated with a wind } \\
\text { energy system so as to be visible from any public road. }\end{array}$ \\
\hline Permits Required & $\begin{array}{l}\text { 1) Special Use Permit, which can expire if the wind energy system is } \\
\text { not installed and functioning within } 5 \text { years from the date the permit is } \\
\text { issued or if the wind energy system is out of service or otherwise unused } \\
\text { for a continuous } 12 \text {-month period } \\
\text { 2) Building Permit }\end{array}$ \\
\hline $\begin{array}{l}\text { Restoration } \\
\text { Requirement }\end{array}$ & $\begin{array}{l}\text { Within } 8 \text { months of receipt of Notice of Abandonment or within } 8 \\
\text { months of providing Notice of Termination of Operations, the owner of } \\
\text { a wind energy system must: } \\
\text { 1) Remove all wind turbines, aboveground improvements, and outdoor } \\
\text { storage } \\
\text { 2) Remove all foundations, pads, and underground electrical wires to a } \\
\text { depth of } 4 \text { feet below the ground surface } \\
\text { 3) Remove all hazardous material from the property and dispose of the } \\
\text { hazardous material in accordance with federal and state law }\end{array}$ \\
\hline Signal Interference & $\begin{array}{l}\text { The owner of a wind energy system must take such reasonable steps as } \\
\text { are necessary to prevent, eliminate, or mitigate any interference with } \\
\text { cellular, radio, or television signals caused by the wind energy system. }\end{array}$ \\
\hline Noise & No noise standards \\
\hline Shadow F & No shadow flicker standards \\
\hline Link & $\begin{array}{l}\text { http://www.henrycty.com/codepartments/zoning/Forms/windzoningordi } \\
\text { nance.pdf }\end{array}$ \\
\hline
\end{tabular}




\section{Rock Island County, Illinois}

\begin{tabular}{|c|c|}
\hline $\begin{array}{l}\text { Zoning Areas } \\
\text { Where Turbines are } \\
\text { Allowed }\end{array}$ & $\begin{array}{l}\text { AG-1 Agricultural Preservation District, AG-2 General Agricultural } \\
\text { District, I-1 Light Industrial District, or I-2 General Industrial District }\end{array}$ \\
\hline Set Backs & $\begin{array}{l}\text { A large wind system shall be located: } \\
\text { 1) } 1,000 \text { feet or more from an occupied structure on an adjoining } \\
\text { property } \\
\text { 2) } 1.1 \text { times the total tower height or more from an occupied structure } \\
\text { on subject property, measured from the wind tower base } \\
\text { 3) } 1.1 \text { times the total tower height from any and all public/private right- } \\
\text { of-way lines, measured from the wind tower base } \\
\text { 4) } 100 \text { feet from all other property lines, measured from the tip of the } \\
\text { blade when located parallel with the ground }\end{array}$ \\
\hline $\begin{array}{l}\text { Spacing and } \\
\text { Density }\end{array}$ & $\begin{array}{l}\text { A wind energy system shall be separated from any other wind energy } \\
\text { system by a minimum of } 200 \text { feet, measured from the tip of the blades } \\
\text { when the blades are parallel with the ground. }\end{array}$ \\
\hline Height & The total height of a wind energy system shall be 500 feet or less. \\
\hline Clearance & $\begin{array}{l}\text { The vertical distance from ground level to the tip of a wind turbine } \\
\text { blade when the blade is at its lowest point must be at least } 25 \text { feet. }\end{array}$ \\
\hline Access & $\begin{array}{l}\text { All wind towers located in a wind energy system, including any } \\
\text { climbing aids, shall be secured against unauthorized access by means of } \\
\text { a locked barrier or security fence } 6 \text { feet in height. }\end{array}$ \\
\hline Electrical Wires & $\begin{array}{l}\text { All electrical wires associated with a wind energy system, other than } \\
\text { wires necessary to connect the wind turbine to its base and to overhead } \\
\text { collection lines, shall be located underground. The board may vary this } \\
\text { requirement upon proof of hardship. }\end{array}$ \\
\hline Lighting & $\begin{array}{l}\text { Required lighting must comply with Federal Aviation Administration } \\
\text { minimum requirements and, whenever possible, be at the lowest } \\
\text { intensity allowed using red lights at night. If more than one lighting } \\
\text { alternative is available, the alternative that causes the least visual } \\
\text { disturbance must be used. }\end{array}$ \\
\hline Equi & $\begin{array}{l}\text { Unless located underground, any electrical equipment associated with a } \\
\text { wind energy system shall be located under the sweep area of a blade } \\
\text { assembly to the extent practicable. }\end{array}$ \\
\hline $\begin{array}{l}\text { Appearance, Color, } \\
\text { and Finish }\end{array}$ & $\begin{array}{l}\text { The exterior surface of any visible components of a wind energy system } \\
\text { must be a non-reflective, neutral color. Wind towers and turbines in an } \\
\text { established wind farm system that are located within } 1,000 \text { feet of each } \\
\text { other must be of uniform design, including tower type, color, number of } \\
\text { blades, and direction of blade rotation to the extent practicable. }\end{array}$ \\
\hline Signs & $\begin{array}{l}\text { No wind turbine, tower, building, or other structure associated with a } \\
\text { wind energy system may be used to advertise or promote any product or } \\
\text { service. No word or graphic representation, other than appropriate } \\
\text { warning signs and owner identification, may be placed on a wind } \\
\text { turbine, tower, building, or other structure associated with a wind } \\
\text { energy system so as to be visible from any public road. }\end{array}$ \\
\hline Permits Required & Special Use Permit, Building Permits \\
\hline
\end{tabular}




\begin{tabular}{|l|l|}
\hline $\begin{array}{l}\text { Restoration } \\
\text { Requirement }\end{array}$ & $\begin{array}{l}\text { 1) Remove all wind turbines, aboveground improvements, and outdoor } \\
\text { storage } \\
\text { 2) Remove all foundations, pads, and underground electrical wires to a } \\
\text { depth of 4 feet below the ground surface } \\
\text { 3) Remove all hazardous materials from the property and dispose of the } \\
\text { hazardous material in accordance with federal and state law } \\
\text { 4) Failure to comply with any of the conditions or restrictions imposed } \\
\text { on a special use permit shall be deemed a violation of the Zoning } \\
\text { Ordinance. }\end{array}$ \\
\hline Signal Interference & $\begin{array}{l}\text { The owner of a wind energy system must take such reasonable steps as } \\
\text { are necessary to prevent, eliminate, or mitigate any interference with } \\
\text { cellular, radio, or television signals caused by the wind energy system. }\end{array}$ \\
\hline Noise & No noise standards \\
\hline Shadow Flicker & No shadow flicker standards \\
\hline Link & $\begin{array}{l}\text { http://www.co.rock-island.il.us/uploadedFiles/ZB/RICounty- } \\
\text { WindEnergyOrd.pdf }\end{array}$ \\
\hline
\end{tabular}




\begin{tabular}{|c|c|}
\hline $\begin{array}{l}\text { Zoning Areas } \\
\text { Where Turbines are } \\
\text { Allowed }\end{array}$ & General Agricultural District \\
\hline Set Backs & $\begin{array}{l}\text { 1) Individual wind turbines shall be set back from all property lines } \\
\text { coincident with or outside of the project boundary a distance equal to } \\
1.5 \text { times the turbine height. } \\
\text { 2) Individual wind turbines shall be set back from all public roads a } \\
\text { distance equal to at least } 1.5 \text { times the turbine height. }\end{array}$ \\
\hline $\begin{array}{l}\text { Spacing and } \\
\text { Density }\end{array}$ & $\begin{array}{l}\text { 1) To avoid objectionable density, there should be adequate spacing } \\
\text { between turbines. } \\
\text { 2) Distinct groupings or clusters of machines shall be limited to no more } \\
\text { than } 12 \text { machines per cluster. A cluster shall be defined as a grouping of } \\
\text { machines that are greater than } 1,320 \text { feet from another grouping. }\end{array}$ \\
\hline Height & $\begin{array}{l}\text { The maximum height of the turbines shall be } 355 \text { feet. Greater height, } \\
\text { but not in excess of } 400 \text { feet, may be considered on a case-by-case basis } \\
\text { if the applicant can sufficiently demonstrate that the increased height } \\
\text { will result in increased energy efficiencies, thereby reducing the overall } \\
\text { number of turbines in the project. However, in all cases, due } \\
\text { consideration shall be given to the scale of the turbines in relation to the } \\
\text { surrounding landscape. }\end{array}$ \\
\hline Clearance & No clearance standards \\
\hline Access & No access standards \\
\hline Electrical Wires & $\begin{array}{l}\text { 1) To avoid visual clutter, intra-project power lines having a voltage of } \\
34,500 \text { volts or less should be buried unless the applicant can } \\
\text { sufficiently demonstrate that burying the lines will violate other } \\
\text { guidelines/standards, violate applicable law, render the project } \\
\text { economically infeasible, or be hidden from public view. } \\
\text { 2) To avoid cluttering the skyline, transformers and other electric } \\
\text { equipment should be hidden from view or otherwise constructed in } \\
\text { harmony with the surrounding landscape. }\end{array}$ \\
\hline Lighting & $\begin{array}{l}\text { Individual wind turbine heights and markings shall comply with Federal } \\
\text { Aviation Administration regulations. If lighting of turbines or other } \\
\text { structures is required, "daytime white-nighttime red" shall be the only } \\
\text { type of lighting allowed unless prohibited by law. }\end{array}$ \\
\hline Equipment & No equipment standards \\
\hline $\begin{array}{l}\text { Appearance, Color, } \\
\text { and Finish }\end{array}$ & $\begin{array}{l}\text { 1) A WECS project should maintain visual unity among clusters of } \\
\text { turbines. } \\
\text { 2) To promote visual uniformity, the rotors, nacelles, and towers of all } \\
\text { turbines in an array should appear similar. } \\
\text { 3) To provide visual order to a WECS project, all turbines shall have the } \\
\text { same number of rotor blades and all rotor blades shall spin in the same } \\
\text { direction in relation to the wind. } \\
\text { 4) To promote visual uniformity, all turbines at a similar ground } \\
\text { elevation shall have the same height from blade tip to the ground. }\end{array}$ \\
\hline
\end{tabular}




\begin{tabular}{|c|c|}
\hline & 5) All turbines and towers shall be a shade of white in color. \\
\hline Signs & $\begin{array}{l}\text { No billboards, logos, and advertising signs of any kind shall be located } \\
\text { on the turbines. }\end{array}$ \\
\hline Permits Required & Special Use Permit, Building Permit \\
\hline $\begin{array}{l}\text { Restoration } \\
\text { Requirement }\end{array}$ & $\begin{array}{l}\text { Standards outlining decommissioning include a "security" that ensures } \\
\text { the turbines will be removed and restoration will be completed no } \\
\text { matter who owns the facility. } \\
\text { All underground equipment and foundation systems of WECS shall be } \\
\text { removed to a depth of at least } 3 \text { feet to allow for cultivation of crops or } \\
\text { restoration of pasture. }\end{array}$ \\
\hline Signal Interference & No signal interference standards \\
\hline Noise & $\begin{array}{l}\text { 1) The noise level caused by the operation of the project, measured at } 5 \\
\text { feet above ground level at the property line coincident with or outside } \\
\text { the project boundary, shall not exceed } 65 \text { decibels (A-weighted) and } \\
\text { shall not exceed } 50 \text { decibels (C-weighted) if it is determined that a pure } \\
\text { tone noise is generated by the project. } \\
\text { 2) Upon receipt by the Riley County Planning and Development } \\
\text { Department of a complaint regarding noise from an existing WECS } \\
\text { project that the Department determines to be reasonable, the project } \\
\text { owner shall be required, at the owner's expense, to have prepared, by an } \\
\text { independent acoustical consultant, approved by the Planning and } \\
\text { Development Department, an acoustical study that shall demonstrate } \\
\text { compliance with the above noise standard on the basis of equivalent } \\
\text { sound pressure levels. "Equivalent sound pressure levels" means the } \\
\text { steady sound level that, over 10-minute measurement periods, would } \\
\text { produce the same energy equivalence as the fluctuating sound level } \\
\text { actually occurring. } \\
\text { 3) Low-frequency noise criteria: WECS that are not designed "in } \\
\text { accordance with proven good engineering practices" shall be prohibited. } \\
\text { WECS designed with the following characteristics shall be deemed in } \\
\text { "accordance with proven good engineering practices:" } \\
\text { a) At least three blades } \\
\text { b) Upwind rotor } \\
\text { c) No furling (where "furling" means that the wind turbine is designed } \\
\text { to limit its power output in high winds by changing the rotor's } \\
\text { plane of rotation to a plane that is not perpendicular to the } \\
\text { prevailing wind direction) } \\
\text { d) Tapered and twisting blades } \\
\text { e) Well-designed braking system }\end{array}$ \\
\hline Shadow Flicker & No shadow flicker standards \\
\hline Link & $\begin{array}{l}\text { http://www.rileycountyks.gov/documents/Planning\%20and\%20Develop } \\
\text { ment/Zoning\%20Regulations/y\%29\%20Section\%2022\%20- } \\
\text { \%20Special\%20Uses.pdf }\end{array}$ \\
\hline
\end{tabular}


Michigan

Banks County, Michigan

\begin{tabular}{|c|c|}
\hline $\begin{array}{l}\text { Zoning Areas } \\
\text { Where Turbines are } \\
\text { Allowed }\end{array}$ & No zoning areas specified \\
\hline Set Backs & $\begin{array}{l}\text { A wind turbine generator or anemometer tower shall, in all cases, be set } \\
\text { back at least a distance equal to the height of the tower from the closest } \\
\text { location in which an off-premise residential structure could be located, } \\
\text { based on the required setbacks for the given zoning district. }\end{array}$ \\
\hline $\begin{array}{l}\text { Spacing and } \\
\text { Density }\end{array}$ & No spacing or density standards \\
\hline Height & $\begin{array}{l}400 \text { feet, but the planning commission may approve an increased height } \\
\text { if it will not result in increased intensity on lighting of the tower due to } \\
\text { Federal Aviation Administration regulations }\end{array}$ \\
\hline Clearance & $\begin{array}{l}\text { The lowest point of the arc created by rotating wind vanes or blades on } \\
\text { a wind generator shall be no less than } 15 \text { feet above the ground. }\end{array}$ \\
\hline Access & No access standards \\
\hline Electrical Wires & $\begin{array}{l}\text { The electrical transmission lines connecting the wind turbine generator } \\
\text { to the public utility electricity distribution system shall be located } \\
\text { underground, unless the Planning Commission finds that it is } \\
\text { technologically infeasible or finds that the cost of placing those } \\
\text { electrical transmission lines underground is unreasonably burdensome. } \\
\text { If the Planning Commission allows overhead electrical transmission } \\
\text { lines to connect the wind turbine generator to the public utility } \\
\text { electricity distribution system, then those electrical transmission lines } \\
\text { shall be placed at a height consistent with industry standards to ensure } \\
\text { public safety. }\end{array}$ \\
\hline Lighting & $\begin{array}{l}\text { Each wind turbine generator or anemometer tower shall not be } \\
\text { artificially lighted, unless required by the Federal Aviation } \\
\text { Administration or other applicable governmental authority. If lighting is } \\
\text { required, the lighting alternatives and design chosen: } \\
\text { 1) Shall be the lowest intensity allowable under Federal Aviation } \\
\text { Administration regulations } \\
\text { 2) Shall not be strobe lighting or other intermittent white lighting } \\
\text { fixtures, unless expressly required by the Federal Aviation } \\
\text { Administration. Such intermittent lighting shall be alternated with } \\
\text { steady red lights at night if acceptable to the Federal Aviation } \\
\text { Administration } \\
\text { 3) May be a red top light that does not pulsate or blink } \\
\text { 4) Shall be shielded to the extent possible and acceptable to the Federal } \\
\text { Aviation Administration to reduce glare and visibility from the ground }\end{array}$ \\
\hline Equipment & No standards \\
\hline $\begin{array}{l}\text { Appearance, Color, } \\
\text { and Finish }\end{array}$ & $\begin{array}{l}\text { 1) Each wind turbine generator shall either maintain a galvanized steel } \\
\text { finish or, subject to any Federal Aviation Administration standards, be } \\
\text { painted a neutral color so as to reduce visual obtrusiveness. } \\
\text { 2) Each wind turbine generator, including all accessory structures, shall, }\end{array}$ \\
\hline
\end{tabular}




\begin{tabular}{|l|l|}
\hline & $\begin{array}{l}\text { to the extent possible, use materials, and colors that will blend them into } \\
\text { the natural setting and surrounding buildings. A medium grey shade is } \\
\text { the preferred color for any wind generator; however, the Planning } \\
\text { Commission may approve an alternate color if the facility is suspected } \\
\text { to be located within an avian migratory route or if an alternate color } \\
\text { would otherwise benefit the community. }\end{array}$ \\
\hline Signs & $\begin{array}{l}\text { A sign no more than } 4 \text { feet square in area displaying an address and } \\
\text { telephone number for emergency calls and informational inquiries shall } \\
\text { be posted at the proposed wind turbine generator or anemometer tower } \\
\text { erected prior to a wind turbine generator. No wind turbine generator } \\
\text { tower or anemometer tower or site shall include any advertising sign. }\end{array}$ \\
\hline Permits Required & Special Use Permit \\
\hline Restoration & $\begin{array}{l}\text { In addition to removing the wind turbine generator or anemometer } \\
\text { tower, the owner shall restore the site of the wind turbine generator or } \\
\text { anemometer to its original condition prior to location of the wind } \\
\text { turbine generator or anemometer tower, subject to reasonable wear and } \\
\text { tear. Any foundation associated with a wind generator or anemometer } \\
\text { tower shall be removed to a minimum depth 3 feet below the final } \\
\text { grade, and site vegetation shall be restored. }\end{array}$ \\
\hline Signal Interference & $\begin{array}{l}\text { Any wind turbine generators shall be constructed and operated so that } \\
\text { they do not interfere with television, microwave, navigational, or radio } \\
\text { reception to neighboring areas. }\end{array}$ \\
\hline Noise & $\begin{array}{l}\text { Any proposed wind turbine generator shall not result in sound levels in } \\
\text { excess of } 60 \text { decibels as measured on the dB(A) scale at the property } \\
\text { lines of the site in question. }\end{array}$ \\
\hline Shadow Flicker & $\begin{array}{l}\text { Landscaping shall be designed to counter the effects of shadow flicker } \\
\text { on any neighboring residences or roadways caused by the rotor rotation } \\
\text { in the sunlight. } \\
\text { http://www.bankstownship.net/article8.pdf }\end{array}$ \\
\hline Link &
\end{tabular}




\section{Huron County, Michigan}

\begin{tabular}{|c|c|}
\hline $\begin{array}{l}\text { Zoning Areas } \\
\text { Where Turbines are } \\
\text { Allowed }\end{array}$ & $\begin{array}{l}\text { WECS may be constructed on land that is zoned Agricultural and within } \\
\text { an area designated as a WECS Overlay District on the official zoning } \\
\text { map for the County, subject to provisions and standards of Section } 5 \\
\text { Wind Energy Conversion Systems Site Plan Review of this Article. }\end{array}$ \\
\hline Set Backs & $\begin{array}{l}\text { 1) Inhabited structures: Each wind turbine shall be set back from the } \\
\text { nearest residence, school, hospital, church, or library a distance no less } \\
\text { than the greater of (a) two times the hub height or (b) } 1,000 \text { feet. } \\
\text { 2) Property lines: Along the border of the Wind Energy Conversion } \\
\text { Systems Overlay District, there shall be a setback distance equal to two } \\
\text { times the hub height of the wind turbine. } \\
\text { 3) Public roads: Each wind turbine shall be set back from the nearest } \\
\text { public road a distance no less than } 400 \mathrm{ft} \text { or } 1.5 \text { times the hub height, } \\
\text { whichever is greater. } \\
\text { 4) Communication and electrical lines: } 400 \text { feet or } 1.5 \text { times hub height }\end{array}$ \\
\hline $\begin{array}{l}\text { Spacing and } \\
\text { Density }\end{array}$ & $\begin{array}{l}\text { Tower separation: At a minimum, separation between towers must be at } \\
\text { least three times the turbine diameter. }\end{array}$ \\
\hline Height & 275 feet, but can be modified \\
\hline Clearance & $\begin{array}{l}\text { The blade tip of any wind turbine shall have ground clearance of no less } \\
\text { than } 75 \text { feet }\end{array}$ \\
\hline Access & $\begin{array}{l}\text { 1) Wind turbines shall not be climbable on the exterior. } \\
\text { 2) All access doors to wind turbine towers and electrical equipment } \\
\text { shall be lockable. }\end{array}$ \\
\hline Electrical Wires & $\begin{array}{l}\text { The electrical collection system shall be placed underground within the } \\
\text { interior of each parcel at a depth designed to accommodate the existing } \\
\text { agricultural land use to the maximum extent practicable. The collection } \\
\text { system may be placed overhead adjacent to county roadways, near } \\
\text { substations or points of interconnection to the electric grid, or in other } \\
\text { areas as necessary }\end{array}$ \\
\hline Lighting & $\begin{array}{l}\text { WECS shall not be artificially lighted, except to the extent required by } \\
\text { the Federal Aviation Administration or other applicable authority, or } \\
\text { otherwise necessary for the reasonable safety and security thereof. }\end{array}$ \\
\hline Equipment & No standards \\
\hline $\begin{array}{l}\text { Appearance, Color, } \\
\text { and Finish }\end{array}$ & $\begin{array}{l}\text { Wind turbines shall be mounted on tubular towers and painted a non- } \\
\text { reflective, non-obtrusive color. The appearance of turbines, towers, and } \\
\text { buildings shall be maintained throughout the life of the WECS pursuant } \\
\text { to industry standards. }\end{array}$ \\
\hline Signs & $\begin{array}{l}\text { Wind turbines shall not be used for displaying any advertising except } \\
\text { for reasonable identification of the manufacturer or operator of the } \\
\text { WECS. Appropriate warning signs shall be placed on wind turbine } \\
\text { towers, electrical equipment, and WECS entrances. }\end{array}$ \\
\hline Permits Required & WECS Permit \\
\hline $\begin{array}{l}\text { Restoration } \\
\text { Requirement }\end{array}$ & $\begin{array}{l}\text { The applicant shall submit a plan describing the intended disposition of } \\
\text { the WECS at the end of their useful life and shall describe any } \\
\text { agreement with the landowner regarding equipment removal upon lease } \\
\text { termination. A performance bond or equivalent financial instrument }\end{array}$ \\
\hline
\end{tabular}




\begin{tabular}{|c|c|}
\hline & $\begin{array}{l}\text { shall be posted in an amount determined by the county [to be utilized in } \\
\text { the event the decommissioning plan needs to be enforced with respect to } \\
\text { tower removal, site restoration, etc.]. The bond shall be in favor of } \\
\text { Huron County and may be provided jointly as a single instrument for } \\
\text { multiple townships within a single wind farm, provided that any such } \\
\text { single instrument shall be in an amount of at least } \$ 1 \text { million and shall } \\
\text { contain a replenishment obligation. }\end{array}$ \\
\hline Signal Interference & $\begin{array}{l}\text { No large-scale WECS shall be installed in any location where its } \\
\text { proximity with existing fixed broadcast, retransmission, or reception } \\
\text { antennas for radio, television, or wireless phone or other personal } \\
\text { communication system would produce electromagnetic interference } \\
\text { with signal transmission or reception. No large-scale WECS shall be } \\
\text { installed in any location along the major axis of an existing microwave } \\
\text { communications link where its operation is likely to produce } \\
\text { electromagnetic interference in the links operation. }\end{array}$ \\
\hline Noise & $\begin{array}{l}\text { 1) Audible noise or the sound pressure from the operation of the WECS } \\
\text { shall not exceed } 50 \mathrm{dBA} \text {, or the ambient sound pressure level plus } 5 \\
\mathrm{dBA} \text {, whichever is greater, for more than } 10 \% \text { of any hour, measured at } \\
\text { any residence, school, hospital, church, or public library existing on the } \\
\text { date of approval of any WECS site permit. The applicant shall be able to } \\
\text { provide sound-pressure-level measurements from a reasonable number } \\
\text { of sampled locations at the perimeter and in the interior of the WECS to } \\
\text { demonstrate compliance with this standard. } \\
\text { 2) In the event audible noise from the operation of the WECS contains a } \\
\text { pure tone, the standards for audible noise set forth in subparagraph a) of } \\
\text { this subsection shall be reduced by } 5 \text { dBA. A pure tone is defined to } \\
\text { exist if the } 1 / 3 \text { octave band sound pressure level in the band, including } \\
\text { the tone, exceeds the arithmetic average of the sound pressure levels of } \\
\text { the two contiguous } 1 / 3 \text { octave bands by } 5 \text { dBA for center frequencies of } \\
500 \mathrm{~Hz} \text { and above, by } 8 \mathrm{dBA} \text { for center frequencies between } 160 \mathrm{~Hz} \text { and } \\
400 \mathrm{~Hz} \text {, or by } 15 \text { dBA for center frequencies less than or equal to } 125 \\
\text { Hz. } \\
\text { 3) The ambient noise level shall be expressed in terms of the highest } \\
\text { whole number sound pressure level in dBA, which is exceeded for more } \\
\text { than } 5 \text { minutes per hour. Ambient noise levels shall be measured at } \\
\text { potentially affected residences, schools, hospitals, churches, and public } \\
\text { libraries. Ambient-noise-level measurement techniques shall employ all } \\
\text { practical means of reducing the effect of wind-generated noise at the } \\
\text { microphone. Ambient-noise-level measurements may be performed } \\
\text { when wind velocities at the proposed project site are sufficient to allow } \\
\text { wind turbine operations, provided that the wind velocity does not } \\
\text { exceed } 30 \text { mph at the ambient-noise-measurement location. } \\
\text { a) Any noise falling between two whole decibels shall be the lower } \\
\text { of the two. } \\
\text { b) In the event the noise levels resulting from the WECS exceed the } \\
\text { criteria listed above, a waiver to said levels may be approved, }\end{array}$ \\
\hline
\end{tabular}




\begin{tabular}{|l|l|}
\hline provided that the following has been accomplished: \\
Written consent from the affected property owners has \\
been obtained stating that they are aware of the WECS \\
and the noise limitations imposed by this Article, and \\
that consent is granted to allow noise levels to exceed the \\
maximum limits otherwise allowed; and \\
$\begin{array}{l}\text { If the applicant wishes the waiver to apply to succeeding } \\
\text { owners of the property, a permanent noise impact } \\
\text { easement must be recorded in the Huron County Register } \\
\text { of Deeds office that describes the benefited and burdened } \\
\text { properties and that advises all subsequent owners of the } \\
\text { burdened property that noise levels in excess of those } \\
\text { otherwise permitted by the ordinance may exist on or at } \\
\text { the burdened property. }\end{array}$ \\
\hline Shadow Flicker & No shadow flicker standards \\
\hline Link & http://www.deq.state.mi.us/documents/deq-ess-p2-agp2- \\
\hline ArticleIII(Revised).pdf
\end{tabular}


Lodi, Michigan

\begin{tabular}{|c|c|}
\hline $\begin{array}{l}\text { Zoning Areas } \\
\text { Where Turbines are } \\
\text { Allowed }\end{array}$ & No Zoning Area Standards \\
\hline Set Backs & $\begin{array}{l}\text { All private and commercial WECS projects must be set back from } \\
\text { property lines at a distance equal to or greater than } 150 \% \text { of the height } \\
\text { of the structure, measured from the base of the structure to the highest } \\
\text { reach of its blade. }\end{array}$ \\
\hline $\begin{array}{l}\text { Spacing and } \\
\text { Density }\end{array}$ & No spacing or density standards \\
\hline Height & $\begin{array}{l}\text { Commercial WECS projects shall be exempt from the height } \\
\text { requirements of this Ordinance, subject to the provisions of Special } \\
\text { Uses, Article 50.0, and compliance with FAA regulations. }\end{array}$ \\
\hline Clearance & No Clearance Standards \\
\hline Access & $\begin{array}{l}\text { 1) Fences with locking portals at least } 6 \text { feet high } \\
\text { 2) Anti-climbing devices } 12 \text { feet from pole base }\end{array}$ \\
\hline Electrical Wires & $\begin{array}{l}\text { All electrical compartments, storage facilities, wire conduit, and } \\
\text { interconnections with utility companies will conform to national and } \\
\text { local electrical codes. }\end{array}$ \\
\hline Lighting & No standards \\
\hline Equipment & No standards \\
\hline $\begin{array}{l}\text { Appearance, Color, } \\
\text { and Finish }\end{array}$ & $\begin{array}{l}\text { Towers and blades shall be painted any neutral color that is acceptable } \\
\text { to Lodi Township or otherwise required by law. }\end{array}$ \\
\hline Signs & $\begin{array}{l}\text { A visible warning sign of "High Voltage" may be required at the base of } \\
\text { all commercial Wind Energy Conversion Systems projects. The sign } \\
\text { must have at a minimum six-inch letters with } 3 / 4 \text {-inch stroke. Such signs } \\
\text { shall be located a maximum of } 300 \text { feet apart and at all points of site } \\
\text { ingress and egress. }\end{array}$ \\
\hline Permits Required & Special Use Permit \\
\hline $\begin{array}{l}\text { Restoration } \\
\text { Requirement }\end{array}$ & $\begin{array}{l}\text { Decommissioning shall include removal of all structures (including } \\
\text { transmission equipment and fencing) and debris to a depth of } 4 \text { feet, } \\
\text { restoration of the soil, and restoration of vegetation within } 6 \text { months of } \\
\text { the end of the project life or facility abandonment. }\end{array}$ \\
\hline Signal Interference & $\begin{array}{l}\text { It shall be the responsibility of the person in charge of the private or } \\
\text { commercial WECS to submit acceptable documentation as part of the } \\
\text { conditional use permit to determine if the WECS project would in any } \\
\text { way cause interference with microwave transmissions, residential } \\
\text { television reception, or radio reception. }\end{array}$ \\
\hline Noise & $\begin{array}{l}\text { The noise level measured at the property line of the property on which } \\
\text { the private or commercial WECS project has been installed shall not } \\
\text { exceed } 55 \text { decibels. }\end{array}$ \\
\hline Shadow Flicker & No shadow flicker standards \\
\hline Link & $\begin{array}{l}\text { http://twp- } \\
\text { lodi.org/services/Lodi\%20Township\%20Zoning\%20Ordinance/Article } \\
\text { \%2055.0\%20-\%20Supplemental\%20Regulations\%20and\%20Standards }\end{array}$ \\
\hline
\end{tabular}


Long Lake Township, Michigan

\begin{tabular}{|c|c|}
\hline $\begin{array}{l}\text { Zoning Areas } \\
\text { Where Turbines are } \\
\text { Allowed }\end{array}$ & No Zoning Area Standards \\
\hline Set Backs & $\begin{array}{l}\text { 1) Large WECS shall maintain a minimum setback from any property } \\
\text { line of two times the combined height of the tower and blade. } \\
\text { 2) Large WECS shall maintain a minimum setback from the right-of- } \\
\text { way line of any public road or highway of at least five times the } \\
\text { combined height of the tower and blade. } \\
\text { 3) In all cases, the large WECS shall maintain a minimum distance of at } \\
\text { least } 1.25 \text { times the tower and blade height from any habitable structure. } \\
\text { 4) In no case shall large WECS be located within any required setback } \\
\text { area nor in any front yard. }\end{array}$ \\
\hline $\begin{array}{l}\text { Spacing and } \\
\text { Density }\end{array}$ & $\begin{array}{l}\text { One additional large Wind Energy Conversion System may be permitted } \\
\text { for each additional land area of not less than } 21 / 2 \text { acres. }\end{array}$ \\
\hline Height & $\begin{array}{l}\text { A large Wind Energy Conversion System shall not exceed a total tower } \\
\text { and blade height of } 150 \text { feet unless the parcel on which the large Wind } \\
\text { Energy Conversion System is to be located is } 10 \text { acres or larger (in } \\
\text { which case the maximum total tower and blade height may be } 300 \text { feet). }\end{array}$ \\
\hline Clearance & $\begin{array}{l}\text { In all cases, the minimum height of the lowest position of the large } \\
\text { Wind Energy Conversion System blade shall be at least } 30 \text { feet above } \\
\text { the ground. }\end{array}$ \\
\hline Access & $\begin{array}{l}\text { Any large Wind Energy Conversion System shall be equipped with anti- } \\
\text { climbing devices. Tower-climbing apparatus shall not be located within } \\
12 \text { feet of the ground. Where a tower is capable of being climbed, a } \\
\text { locked, protective fence at least } 6 \text { feet high shall enclose the tower. }\end{array}$ \\
\hline Electrical Wires & No electrical wire standards \\
\hline Lighting & $\begin{array}{l}\text { Large WECS shall be equipped with air traffic warning lights or other } \\
\text { marking lights only if required by the Federal Aviation Administration; } \\
\text { such light should be positioned or shielded to avoid undue visual impact } \\
\text { on neighboring properties. }\end{array}$ \\
\hline Equipment & No standards \\
\hline $\begin{array}{l}\text { Appearance, Color, } \\
\text { and Finish }\end{array}$ & $\begin{array}{l}\text { Colors and surface treatments of the large WECS and supporting } \\
\text { structures shall, to the greatest extent feasible, minimize disruption of } \\
\text { the natural characteristics of the site and shall include no advertising of } \\
\text { any kind. }\end{array}$ \\
\hline Signs & $\begin{array}{l}\text { Large WECS shall include no sign or advertising of any kind, except for } \\
\text { one sign (not to exceed } 2 \text { square feet) posted at the base of the tower; } \\
\text { said sign shall contain the following information: } \\
\text { a) "Warning: High Voltage" } \\
\text { b) Manufacturer's name } \\
\text { c) Operator's name } \\
\text { d) Emergency phone number } \\
\text { e) Emergency shutdown procedure }\end{array}$ \\
\hline Permits Required & Conditional Land Use Permit \\
\hline
\end{tabular}




\begin{tabular}{|l|l|}
\hline Restoration & $\begin{array}{l}\text { If any large WECS remain non-functional or inoperative for a } \\
\text { continuous period of 1 year, the permittee shall remove said system at } \\
\text { their expense. Removal of the system shall mean the entire structure, } \\
\text { including foundations, transmission equipment, and fencing, from the } \\
\text { property. If removal of towers and appurtenant facilities is required and } \\
\text { the permit holder or successors fails to remove the towers and } \\
\text { appurtenant facilities from the property within 30 days from the date of } \\
\text { notification by the Zoning Administrator, Long Lake Township may } \\
\text { proceed to remove the towers and appurtenant facilities; in which case, } \\
\text { the salvage becomes property of the Township; and costs of removing } \\
\text { the facilities will remain the burden of the permit holder. To ensure } \\
\text { removal of an obsolete, inoperable, or abandoned facility, the Township } \\
\text { may require of the applicant a financial guarantee as provided in Section } \\
\text { 24.8. }\end{array}$ \\
\hline Signal Interference & $\begin{array}{l}\text { Large WECS shall be designed and constructed so as not to cause radio } \\
\text { and television interference. }\end{array}$ \\
\hline Noise & $\begin{array}{l}\text { Large WECS shall be designed and placed in such a manner to } \\
\text { minimize, to the greatest extent feasible, adverse visual and noise } \\
\text { impacts on neighboring areas. Noise shall be limited to no more than 10 } \\
\text { decibels above the original ambient baseline sound level beyond the } \\
\text { property line, as reported in the noise study as required under 14.35.1.a } \\
\text { above. }\end{array}$ \\
\hline Shadow Flicker & $\begin{array}{l}\text { During the impact analysis of the large WECS, written documentation } \\
\text { shall be provided projecting 1) the shadow flicker on any existing } \\
\text { structures located off the property on which the large system will be } \\
\text { constructed, and 2) the extent and duration of the shadow flickers on } \\
\text { these existing structures. }\end{array}$ \\
\hline $\begin{array}{l}\text { http://www.longlaketownship.com/planning/June\%2008/wind-turbine- } \\
\text { ordinance.pdf }\end{array}$ \\
\hline
\end{tabular}


Minnesota

Big Stone County, Minnesota

\begin{tabular}{|c|c|}
\hline $\begin{array}{l}\text { Zoning Areas } \\
\text { Where Turbines are } \\
\text { Allowed }\end{array}$ & $\begin{array}{l}\text { Commercial wind turbines may be located with a conditional use permit } \\
\text { in the following areas: District A-1, A-2, Commercial/Industrial }\end{array}$ \\
\hline Set Backs & $\begin{array}{l}\text { 1) Property lines: } 1.1 \text { times the total height } \\
\text { 2) Neighboring dwellings: } 750 \text { feet } \\
\text { 3) Road rights-of-way: } 1.1 \text { times the total height or } 150 \text { feet to the } \\
\text { center of the abutting road, whichever is greater } \\
\text { 4) Other rights-of-way: } 1.1 \text { times the total height } \\
\text { 5) Public conservation land: } 600 \text { feet } \\
\text { 6) Wetlands: } 600 \text { feet } \\
\text { 7) Other structures: } 1.1 \text { times the total height } \\
\text { 8) Existing WECS: To be considered based on relative size of the } \\
\text { existing and proposed systems and the alignment of the systems relative } \\
\text { to the predominant winds } \\
\text { 9) Big Stone Lake and Minnesota River Bluff: } 1 / 4 \text { mile minimum; per } \\
\text { setbacks in Conditional Use Permit }\end{array}$ \\
\hline $\begin{array}{l}\text { Spacing and } \\
\text { Density }\end{array}$ & No spacing and density standards \\
\hline Height & $\begin{array}{l}\text { No height standard for commercial WECS (Non-Commercial must be } \\
\text { less than } 200 \text { feet) }\end{array}$ \\
\hline Clearance & $\begin{array}{l}\text { Rotor blades or airfoils must maintain at least } 12 \text { feet of clearance } \\
\text { between their lowest point and the ground. }\end{array}$ \\
\hline Access & No access standards \\
\hline Electrical Wires & $\begin{array}{l}\text { All communication and feeder lines, equal to or less than } 34.5 \mathrm{kV} \text { in } \\
\text { capacity, installed as part of WECS shall be buried where reasonably } \\
\text { feasible. Feeder lines installed as part of WECS shall not be considered } \\
\text { an essential service. This standard applies to all feeder lines subject to } \\
\text { Big Stone County authority. }\end{array}$ \\
\hline Lighting & $\begin{array}{l}\text { Lighting, including lighting intensity and strobe frequency, shall adhere } \\
\text { to but not exceed requirements established by FAA permits and } \\
\text { regulations. Red strobe lights are preferred for nighttime illumination to } \\
\text { reduce impacts on migrating birds. Red pulsating incandescent lights } \\
\text { should be avoided. Exception may be made for meteorological towers, } \\
\text { where concerns exist relative to aerial spray applicators. }\end{array}$ \\
\hline Equipment & No standards \\
\hline $\begin{array}{l}\text { Appearance, Color, } \\
\text { and Finish }\end{array}$ & $\begin{array}{l}\text { All commercial wind turbines shall be white, grey, or another non- } \\
\text { obtrusive color. Blades may be black to facilitate de-icing. Finishes } \\
\text { shall be matte or non-reflective. Exception may be made for } \\
\text { meteorological towers, where concerns exist relative to aerial spray } \\
\text { applicators. }\end{array}$ \\
\hline Signs & $\begin{array}{l}\text { All signage on site shall comply with Section } 8 \text { of the Big Stone County } \\
\text { Land and Related Resource Management Ordinance. The manufacturers } \\
\text { or owner's company name and/or logo must be placed on the nacelle. }\end{array}$ \\
\hline
\end{tabular}




\begin{tabular}{|l|l|}
\hline Permits Required & $\begin{array}{l}\text { Land Use Permit, Conditional Use Permit, no fee listed. Also, according } \\
\text { to Minnesota statute 216F.04, the Public Utilities Commission must } \\
\text { issue a site permit. }\end{array}$ \\
\hline $\begin{array}{l}\text { Restoration } \\
\text { Requirement }\end{array}$ & $\begin{array}{l}\text { Commercial WECS shall have a decommissioning plan outlining the } \\
\text { anticipated means and cost of removing WECS at the end of their } \\
\text { serviceable life or upon becoming discontinued. The cost estimates shall } \\
\text { be provided by a competent party, such as a professional engineer, a } \\
\text { contractor capable of decommissioning, or a person with suitable } \\
\text { expertise or experience with decommissioning. The plan shall also } \\
\text { identify the financial resources that will be available to pay for the } \\
\text { decommissioning and removal of WECS and accessory facilities. }\end{array}$ \\
\hline Signal Interference & $\begin{array}{l}\text { The applicant shall minimize or mitigate interference with } \\
\text { electromagnetic communications, such as radio, telephone, microwaves, } \\
\text { or television signals caused by WECS. The applicant shall notify all } \\
\text { communication tower operators within 2 miles of proposed WECS upon } \\
\text { application to the county for permits. No WECS shall be constructed so } \\
\text { as to interfere with County or Minnesota Department of Transportation } \\
\text { microwave transmissions. }\end{array}$ \\
\hline Noise & All WECS shall comply with Minnesota Rules 7030 governing noise. \\
\hline Shadow Flicker & No shadow flicker standards \\
\hline Link & http://www.bigstonecounty.org/BSCWindPowerOrdinance.pdf \\
\hline
\end{tabular}




\section{Brown County, Minnesota}

\begin{tabular}{|c|c|}
\hline $\begin{array}{l}\text { Zoning Areas } \\
\text { Where Turbines are } \\
\text { Allowed }\end{array}$ & Agriculture/ Shoreland Protection (A-1) \\
\hline Set Backs & $\begin{array}{l}\text { 1) Property lines: } 1.5 \text { times the total height } \\
\text { 2) Neighboring dwellings: } 750 \text { feet } \\
\text { 3) Road rights-of-way: } 1.5 \text { times the total height } \\
\text { 4) Other rights-of-way (railroad, power line, etc.): } 1.5 \text { times the total } \\
\text { height } \\
\text { 5) River bluffs: } 750 \text { feet }\end{array}$ \\
\hline $\begin{array}{l}\text { Spacing and } \\
\text { Density }\end{array}$ & No spacing and density standards. \\
\hline Height & 200 feet \\
\hline Clearance & $\begin{array}{l}\text { Rotor blades or airfoils must maintain at least } 12 \text { feet of clearance } \\
\text { between their lowest point and the ground. }\end{array}$ \\
\hline Access & No access standards \\
\hline Electrical Wires & $\begin{array}{l}\text { All communication and feeder lines, equal to or less than } 34.5 \mathrm{kV} \text { in } \\
\text { capacity, installed as part of WECS shall be buried (where reasonably } \\
\text { feasible). Feeder lines installed as part of WECS shall not be considered } \\
\text { an essential service. This standard applies to all feeder lines subject to } \\
\text { Brown County authority. }\end{array}$ \\
\hline Lighting & $\begin{array}{l}\text { Lighting, including lighting intensity and strobe frequency, shall adhere } \\
\text { to but not exceed requirements established by Federal Aviation } \\
\text { Administration permits and regulations. Red strobe lights are preferred } \\
\text { for nighttime illumination to reduce impacts on migrating birds. Red } \\
\text { pulsating incandescent lights should be avoided. }\end{array}$ \\
\hline \multicolumn{2}{|l|}{ Equipment } \\
\hline $\begin{array}{l}\text { Appearance, Color, } \\
\text { and Finish }\end{array}$ & $\begin{array}{l}\text { All wind turbines and towers that are part of commercial WECS shall be } \\
\text { white, grey, or another unobtrusive color. Blades may be black to } \\
\text { facilitate de-icing. Finishes shall be matte or non-reflective. The } \\
\text { exception is made for meteorological towers, where concerns exist } \\
\text { relative to aerial spray applicators. }\end{array}$ \\
\hline Signs & $\begin{array}{l}\text { 1) For all commercial WECS, a sign or signs shall be posted on the } \\
\text { tower, transformer, and substation warning of high voltage. Signs with } \\
\text { emergency contact information shall also be posted on the turbine or at } \\
\text { another suitable point. } \\
\text { 2) All signage on site shall comply with Section } 727 \text { Sign Regulations } \\
\text { of the Brown County Ordinance. The manufacturer's or owner's } \\
\text { company name and/or logo may be placed on the nacelles of the WECS. }\end{array}$ \\
\hline Permits Required & Conditional Use Permit \\
\hline $\begin{array}{l}\text { Restoration } \\
\text { Requirement }\end{array}$ & $\begin{array}{l}\text { All WECS and accessory facilities shall be removed to } 4 \text { feet below } \\
\text { ground level within } 90 \text { days of the discontinuation of use. WECS also } \\
\text { need a decommissioning plan. }\end{array}$ \\
\hline Signal Interference & $\begin{array}{l}\text { The applicant shall minimize or mitigate interference with } \\
\text { electromagnetic communications, such as radio, telephone, microwaves, } \\
\text { or television signals caused by WECS. The applicant shall notify all }\end{array}$ \\
\hline
\end{tabular}




\begin{tabular}{|l|l|}
\hline & $\begin{array}{l}\text { communication tower operators within 5 miles of the proposed WECS } \\
\text { location upon application to the county for permits. No WECS shall be } \\
\text { constructed so as to interfere with County or Minnesota Department of } \\
\text { Transportation microwave transmissions. }\end{array}$ \\
\hline Noise & All WECS shall comply with Minnesota Rule 7030 governing noise. \\
\hline Shadow Flicker & No shadow flicker standards \\
\hline Link & $\begin{array}{l}\text { http://www.co.brown.mn.us/departments/Crthouse/PlanZone/zoningordi } \\
\text { nance.pdf }\end{array}$ \\
\hline
\end{tabular}


Fillmore County, Minnesota

\begin{tabular}{|c|c|}
\hline $\begin{array}{l}\text { Zoning Areas } \\
\text { Where Turbines are } \\
\text { Allowed }\end{array}$ & A-1, B-1, I-1 \\
\hline Set Backs & $\begin{array}{l}\text { 1) All wind turbines and meteorological towers shall be set back } 1.1 \\
\text { times their height from all property lines and road rights of way. } \\
\text { 2) The construction of all new turbines and meteorological towers must } \\
\text { be at least } 750 \text { feet from a dwelling unless the dwelling owner and } \\
\text { turbine/tower owner are the same. } \\
\text { 3) All new dwellings must be set back } 750 \text { feet from any wind turbine } \\
\text { or meteorological tower unless the dwelling owner and turbine/tower } \\
\text { owner are the same. }\end{array}$ \\
\hline $\begin{array}{l}\text { Spacing and } \\
\text { Density }\end{array}$ & No spacing and density standards \\
\hline Height & $\begin{array}{l}\text { Non-commercial WECS shall have a total height of less than } 200 \text { feet; } \\
\text { no standards for commercial }\end{array}$ \\
\hline Clearance & $\begin{array}{l}\text { Rotor blades or airfoils must maintain at least } 12 \text { feet of clearance } \\
\text { between their lowest point and the ground. }\end{array}$ \\
\hline Access & No access standards \\
\hline Electrical Wires & $\begin{array}{l}\text { 1) Feeder lines: All communication and feeder lines equal to or less than } \\
34.5 \mathrm{kV} \text { in capacity, installed as part of WECS shall be buried (where } \\
\text { reasonably feasible). Feeder lines installed as part of WECS shall not be } \\
\text { considered an essential service. This standard applies to all feeder lines } \\
\text { subject to Fillmore County authority. } \\
\text { 2) All WECS and accessory equipment and facilities shall comply with } \\
\text { the National Electric Code and other applicable standards. }\end{array}$ \\
\hline Lighting & $\begin{array}{l}\text { Lighting, including lighting intensity and strobe frequency, shall adhere } \\
\text { to but not exceed requirements established by Federal Aviation } \\
\text { Administration permits and regulations. Red strobe lights are preferred } \\
\text { for nighttime illumination to reduce impacts on migrating birds. Red } \\
\text { pulsating incandescent lights are discouraged. }\end{array}$ \\
\hline Equipment & No equipment standards \\
\hline $\begin{array}{l}\text { Appearance, Color, } \\
\text { and Finish }\end{array}$ & $\begin{array}{l}\text { All commercial wind turbines and meteorological towers that are part of } \\
\text { commercial WECS shall be white, grey, or another unobtrusive color. } \\
\text { Blades may be black to facilitate de-icing. Finishes may be matte or } \\
\text { non-reflective. The Zoning Administrator may make exceptions for } \\
\text { meteorological towers, where concerns exist relative to aerial spray } \\
\text { applicators. }\end{array}$ \\
\hline Signs & $\begin{array}{l}\text { 1) For commercial WECS. a sign or signs shall be posted on the tower, } \\
\text { transformer, and substation warning of high voltage. Signs with } \\
\text { emergency contact information shall also be posted on the turbine or at } \\
\text { another suitable point. } \\
\text { 2) All signage on the site shall comply with Section } 726 \text { of the Fillmore } \\
\text { County Zoning Ordinance. The manufacturer's or owner's company } \\
\text { name and/or logo may be placed on the nacelle compartment containing } \\
\text { the electrical generator. }\end{array}$ \\
\hline
\end{tabular}




\begin{tabular}{|l|l|}
\hline Permits Required & Land Use Permit, Conditional Use Permit \\
\hline Restoration & $\begin{array}{l}\text { 1) All WECS and accessory facilities shall be removed 4 feet below } \\
\text { ground level within 90 days of the discontinuation of use. } \\
\text { 2) Commercial WECS shall have decommissioning plans outlining the } \\
\text { anticipated means and cost of removing WECS at the end of their } \\
\text { serviceable life or upon becoming discontinued. The cost estimates shall } \\
\text { be provided by a competent party; such as a professional engineer, a } \\
\text { contractor capable of decommissioning, or a person with suitable } \\
\text { expertise or experience with decommissioning. The plan shall also } \\
\text { identify the financial resources that will be available to pay for the } \\
\text { decommissioning and removal of the WECS and accessory facilities. }\end{array}$ \\
\hline Signal Interference & $\begin{array}{l}\text { The applicant shall minimize or mitigate interference with } \\
\text { electromagnetic communications, such as radio, telephone, microwaves, } \\
\text { or television signals caused by WECS. The applicant shall notify all } \\
\text { communication tower operators within 2 miles of the proposed WECS } \\
\text { location upon application to the county for permits. No WECS shall be } \\
\text { constructed as to interfere with County or Minnesota Department or } \\
\text { Transportation microwave transmissions. }\end{array}$ \\
\hline Noise & $\begin{array}{l}\text { All WECS shall comply with Minnesota Rules 7030, as amended, } \\
\text { governing noise. }\end{array}$ \\
\hline Shadow Flicker & No shadow flicker standards \\
\hline Link & $\begin{array}{l}\text { http://www.co.fillmore.mn.us/zoning/documents/2008wind energy_con } \\
\text { version systems ord.pdf }\end{array}$ \\
\hline
\end{tabular}




\section{Lyon County, Minnesota}

\begin{tabular}{|c|c|}
\hline $\begin{array}{l}\text { Zoning Areas } \\
\text { Where Turbines are } \\
\text { Allowed }\end{array}$ & $\begin{array}{l}\text { Conditionally permitted in the following districts: agricultural, urban } \\
\text { expansion, highway commercial, rural residential }\end{array}$ \\
\hline Set Backs & $\begin{array}{l}\text { 1) } 1.1 \text { times total tower height from property lines } \\
\text { 2) } 1,000 \text { feet from neighboring dwellings } \\
\text { 3) } 600 \text { feet from public conservation lands managed as grasslands } \\
\text { 4) } 600 \text { feet from wetlands, USFW types III, IV, and V } \\
\text { 5) Roads: } 1 \text { times the total height; may be reduced for minimum } \\
\text { maintenance roads or a road with an average daily traffic count of less } \\
\text { than } 10\end{array}$ \\
\hline $\begin{array}{l}\text { Spacing and } \\
\text { Density }\end{array}$ & $\begin{array}{l}\text { To be considered based on relative size of the existing and proposed } \\
\text { WECS, alignment of the WECS relative to the predominant winds, } \\
\text { topography, extent of wake interference impact on existing WECS, } \\
\text { property line setback of existing WECS }\end{array}$ \\
\hline Height & $\begin{array}{l}\text { Non-commercial WECS shall have a total height of less than } 200 \text { feet. } \\
\text { No remarks for commercial WECS }\end{array}$ \\
\hline Clearance & $\begin{array}{l}\text { Rotor blades or airfoils must maintain at least } 30 \text { feet of clearance } \\
\text { between their lowest point and the ground. }\end{array}$ \\
\hline Access & No access standards \\
\hline Electrical & All feeder lines equal t \\
\hline Lighting & $\begin{array}{l}\text { Lighting, including lighting intensity and strobe frequency, shall adhere } \\
\text { to but not exceed requirements established by FAA permits and } \\
\text { regulations. Red strobe lights are preferred for nighttime illumination to } \\
\text { reduce impacts on migrating birds. Red pulsating incandescent lights } \\
\text { should be avoided. }\end{array}$ \\
\hline Equipment & No equipment standards \\
\hline $\begin{array}{l}\text { Appearance, Color, } \\
\text { and Finish }\end{array}$ & $\begin{array}{l}\text { All wind turbines and towers that are part of commercial WECS shall be } \\
\text { white, grey, or another non-obtrusive color. Blades may be black to } \\
\text { facilitate de-icing. Finishes shall be matte or non-reflective. }\end{array}$ \\
\hline Signs & $\begin{array}{l}\text { All signage on site shall comply with Article } 17 \text { of the Lyon County } \\
\text { Zoning Ordinance. The manufacturer's or owner's company and/or logo } \\
\text { may be placed on the nacelles of the WECS. }\end{array}$ \\
\hline Permits Required & $\begin{array}{l}\text { Land Use Permit, Conditional Use Permit. Also, according to Minnesota } \\
\text { Statute 216F.04, the Public Utilities Commission must issue a site } \\
\text { permit. }\end{array}$ \\
\hline $\begin{array}{l}\text { Restoration } \\
\text { Requirement }\end{array}$ & $\begin{array}{l}\text { WECS shall be considered a discontinued use after } 1 \text { year without } \\
\text { energy production. All WECS and accessory facilities shall be removed } \\
4 \text { feet below ground level within } 90 \text { days of the discontinuation of use. }\end{array}$ \\
\hline Signal Interference & $\begin{array}{l}\text { The applicant shall minimize or mitigate interference with } \\
\text { electromagnetic communications, such as radio, telephone, microwaves, } \\
\text { or television signals caused by WECS. The applicant shall notify all } \\
\text { communication tower operators within } 2 \text { miles of the proposed WECS } \\
\text { location upon application to the county for permits. }\end{array}$ \\
\hline Noise & $\begin{array}{l}\text { All WECS shall comply with Minnesota Rules 7030, as amended, } \\
\text { governing noise. }\end{array}$ \\
\hline
\end{tabular}




\begin{tabular}{|l|l|}
\hline Shadow Flicker & No shadow flicker standards \\
\hline Link & http://www.lyonco.org/depts/publicworks/pz/windordinancechanges.pdf \\
\hline
\end{tabular}




\section{Martin County, Minnesota}

\begin{tabular}{|c|c|}
\hline $\begin{array}{l}\text { Zoning Areas } \\
\text { Where Turbines are } \\
\text { Allowed }\end{array}$ & Agricultural District, Business and Industry Districts \\
\hline Set Backs & $\begin{array}{l}\text { 1) Rights-of-way: All WECS must be set back from roads rights-of-way } \\
\text { a distance that is equal to or greater than the height of the WECS as } \\
\text { measured from the ground level to the top of the tower, the top of the } \\
\text { rotor, or blade, whichever is higher. (The setback may be reduced to a } \\
\text { distance agreed upon by the County if the applicant furnishes a } \\
\text { registered engineer's certification that the WECS are designed to } \\
\text { collapse, fall, curl, or bend within a distance or zone shorter than the } \\
\text { height of the WECS.) } \\
\text { 2) Property lines: All WECS must be set back from property lines a } \\
\text { distance equal to or greater than the height of the WECS as measured } \\
\text { from the ground level to the top of the tower, the top of the rotor, or } \\
\text { blade, whichever is higher. (The setback may be reduced to a distance } \\
\text { agreed upon by the County if the applicant furnishes a registered } \\
\text { engineer's certification that the WECS is designed to collapse, fall, curl, } \\
\text { or bend within a distance or zone shorter than the height of the WECS. } \\
\text { The setback may be reduced to a distance agreed upon by the County if } \\
\text { there are no structures within the fall zone and if an easement is } \\
\text { obtained from the adjacent landowner or landowners. The easement } \\
\text { must describe all lands that could be impacted if the tower fell and must } \\
\text { be in effect as long as the WECS are in place.) } \\
\text { 3) Dwellings: All commercial WECS shall be set back } 750 \text { feet from } \\
\text { dwellings other than the applicant's dwelling. }\end{array}$ \\
\hline $\begin{array}{l}\text { Spacing and } \\
\text { Density }\end{array}$ & No spacing and density standards \\
\hline Height & No height standards \\
\hline Clearance & WECS blades must be a minimum of 30 feet above ground level. \\
\hline Access & $\begin{array}{l}\text { The WECS must be guarded against unauthorized climbing. It shall } \\
\text { either have the climbing apparatus not closer than } 12 \text { feet to the ground } \\
\text { or be un-climbable by design for the first } 12 \text { feet. }\end{array}$ \\
\hline Electrical Wires & $\begin{array}{l}\text { The WECS electrical equipment must adhere to all state, federal, and } \\
\text { power company rules, regulations, and standards. }\end{array}$ \\
\hline Lighting & $\begin{array}{l}\text { WECS may not be illuminated unless required by a state or federal } \\
\text { agency. }\end{array}$ \\
\hline Equipment & No equipment standards \\
\hline $\begin{array}{l}\text { Appearance, Color, } \\
\text { and Finish }\end{array}$ & $\begin{array}{l}\text { Towers and blades shall be painted white, grey, or another non- } \\
\text { reflective, unobtrusive color. }\end{array}$ \\
\hline Signs & $\begin{array}{l}\text { Signs must be posted at the base of each tower that specifies the } \\
\text { following information: "Warning High Voltage," manufacturer's name, } \\
\text { emergency shutdown procedures, and emergency phone numbers. No } \\
\text { permitted sign may exceed } 3 \text { square feet in area. Signs other than } \\
\text { warning signs, equipment labels, emergency information, or owner } \\
\text { identification are prohibited on WECS. }\end{array}$ \\
\hline
\end{tabular}




\begin{tabular}{|l|l|}
\hline Permits Required & Conditional Use Permit \\
\hline Requirement & $\begin{array}{l}\text { The permit application must contain a decommissioning plan to ensure } \\
\text { that the project is properly decommissioned upon facility abandonment. } \\
\text { At a minimum, the decommissioning plan shall include: } \\
\text { 1) Provisions for the removal of all structures, debris, and above-ground } \\
\text { cabling within 180 days after facility abandonment } \\
\text { 2) Provisions for the restoration of the soil and vegetation within 270 } \\
\text { days after facility abandonment }\end{array}$ \\
\hline Signal Interference & $\begin{array}{l}\text { No WECS shall be permitted that cause any interference with } \\
\text { commercial or private use and enjoyment of other legally operating } \\
\text { telecommunication devices including but not limited to radios, } \\
\text { television, telephones, personal communication devices, and other } \\
\text { electronic equipment and devices. }\end{array}$ \\
\hline Noise & $\begin{array}{l}\text { The WECS must be operated and maintained so that they comply with } \\
\text { the noise pollution standards of the Minnesota Pollution Control } \\
\text { Agency. }\end{array}$ \\
\hline Shadow Flicker & No shadow flicker standards \\
\hline Link & http://www.co.martin.mn.us/Plan\&Zone/Docs/WIND\%20ENERGY.pdf \\
\hline
\end{tabular}




\section{Nicollet County, Minnesota}

\begin{tabular}{|c|c|}
\hline $\begin{array}{l}\text { Zoning Areas } \\
\text { Where Turbines are } \\
\text { Allowed }\end{array}$ & Agriculture, Conservancy, General Business, Limited Industry \\
\hline Set Backs & $\begin{array}{l}\text { 1) Property lines: } 1.1 \text { times the total height } \\
\text { 2) Neighboring dwellings: } 750 \text { feet } \\
\text { 3) Road rights-of-way: } 1.1 \text { times the total height } \\
\text { 4) Other rights-of-way (railroads, power lines, etc.): } 1.1 \text { times the total } \\
\text { height } \\
\text { 5) Public conservation lands: } 600 \text { feet } \\
\text { 6) Wetlands, USFW Types III, IV, V: } 600 \text { feet } \\
\text { 7) Minnesota River Valley: } 1 / 2 \text { mile } \\
\text { 8) Other existing WECS: to be based on: } \\
\text { a) Relative size of the existing and proposed WECS } \\
\text { b) Alignment of the WECS relative to the predominant winds } \\
\text { c) Topography } \\
\text { d) Extent of the wake interference on existing WECS } \\
\text { e) Property line setbacks of existing WECS } \\
\text { f) Other setbacks required }\end{array}$ \\
\hline $\begin{array}{l}\text { Spacing and } \\
\text { Density }\end{array}$ & No spacing and density standards \\
\hline Height & $\begin{array}{l}\text { Non-commercial WECS shall have a total height of less than } 200 \text { feet; } \\
\text { no standard for commercial WECS }\end{array}$ \\
\hline Clearance & $\begin{array}{l}\text { Rotor blades and airfoils must maintain at least } 12 \text { feet of clearance } \\
\text { between their lowest points and the ground }\end{array}$ \\
\hline Access & No access standards \\
\hline Electrical Wires & $\begin{array}{l}\text { All communications and feeder lines equal to or less than } 34.5 \mathrm{kV} \text { in } \\
\text { capacity installed as part of WECS shall be buried, where reasonably } \\
\text { feasible. This standard applies to all feeder lines subject to Nicollet } \\
\text { County authority. }\end{array}$ \\
\hline Lighting & $\begin{array}{l}\text { Lighting, including lighting intensity and strobe frequency, shall adhere } \\
\text { to but not exceed requirements established by Federal Aviation } \\
\text { Administration permits and regulations. Red strobe lights are required } \\
\text { for nighttime illumination to reduce impacts on migrating birds. }\end{array}$ \\
\hline Equipment & No equipment standards \\
\hline $\begin{array}{l}\text { Appearance, Color, } \\
\text { and Finish }\end{array}$ & $\begin{array}{l}\text { All wind turbines and towers that are part of commercial WECS shall be } \\
\text { white, grey, or another non-obtrusive color. Blades may be black to } \\
\text { facilitate de-icing. Finishes shall be matte or non-reflective. Exceptions } \\
\text { may be made for meteorological towers, where concerns exist relative to } \\
\text { aerial spray applicators. }\end{array}$ \\
\hline Signs & $\begin{array}{l}\text { 1) For all commercial WECS, a sign or signs shall be posted on the } \\
\text { tower, transformer, and substation warning of high voltage. Signs with } \\
\text { emergency contact information shall also be posted on the turbine or at } \\
\text { another suitable point. } \\
\text { 2) All signage on site shall comply with Section } 7 \text { of the Nicollet } \\
\text { County Zoning Ordinance. The manufacturer's or owner's name and/or }\end{array}$ \\
\hline
\end{tabular}




\begin{tabular}{|l|l|}
\hline & logo may be placed on the nacelles of the WECS. \\
\hline Permits Required & Conditional Use Permit, Zoning Permit \\
\hline $\begin{array}{l}\text { Restoration } \\
\text { Requirement }\end{array}$ & $\begin{array}{l}\text { All WECS and accessory facilities shall be removed to 4 feet below } \\
\text { ground level within 90 days of the discontinuation of use. } \\
\text { Decommissioning plan also needed }\end{array}$ \\
\hline Signal Interference & $\begin{array}{l}\text { The applicant shall minimize interference with existing electromagnetic } \\
\text { communications such as radio, telephone, microwaves, or television } \\
\text { signals caused by WECS. The applicant shall notify all communication } \\
\text { tower operators within 5 miles of the proposed WECS location upon } \\
\text { application to the county for permits. }\end{array}$ \\
\hline Noise & All WECS shall comply with Minnesota Rules 7030 governing noise. \\
\hline Shadow Flicker & No shadow flicker standards \\
\hline Link & $\begin{array}{l}\text { http://www.co.nicollet.mn.us/File.aspx?Id=FD792355-907D-4233- } \\
\text { 8AFB-E67DA3F7907C }\end{array}$ \\
\hline
\end{tabular}




\section{Swift County, Minnesota}

\begin{tabular}{|c|c|}
\hline $\begin{array}{l}\text { Zoning Areas } \\
\text { Where Turbines are } \\
\text { Allowed }\end{array}$ & $\begin{array}{l}\text { Agricultural Preservation District \# 1, Agricultural Preservation District } \\
\text { \# 2, Agricultural Preservation District \# 3, Agricultural Preservation } \\
\text { District \# 4, Urban Development District }\end{array}$ \\
\hline Set Backs & $\begin{array}{l}\text { 1) Property lines: } 1.1 \text { times the total height } \\
\text { 2) Neighboring dwellings: } 750 \text { feet } \\
\text { 3) Road rights-of-way: } 1 \text { times the height; may be reduced for minimum } \\
\text { maintenance roads or a road with an average daily traffic count of less } \\
\text { than } 10 \\
\text { 4) Other rights-of-way (railroads, power lines, etc.): to be considered by } \\
\text { the planning commission } \\
\text { 5) Public conservation lands managed as grasslands: } 600 \text { feet } \\
\text { 6) Wetlands, USFW Types III, IV, and V: } 600 \text { feet } \\
\text { 7) Other structures: to be considered } \\
\text { 8) Other existing WECS: N/A }\end{array}$ \\
\hline $\begin{array}{l}\text { Spacing and } \\
\text { Density }\end{array}$ & No spacing and density standards \\
\hline Height & $\begin{array}{l}\text { Small-scale WECS shall have a total height of less than } 200 \text { feet. No } \\
\text { standards for large WECS }\end{array}$ \\
\hline Clearance & $\begin{array}{l}\text { Rotor blades or airfoils must maintain at least } 12 \text { feet of clearance } \\
\text { between their lowest points and the ground. }\end{array}$ \\
\hline Access & No access standards \\
\hline Electrical Wires & $\begin{array}{l}\text { All communication and feeder lines equal to or less than } 34.5 \mathrm{kV} \text { in } \\
\text { capacity installed as part of WECS shall be buried where reasonably } \\
\text { feasible. Feeder lines installed as part of WECS shall not be considered } \\
\text { an essential service. This standard applies to all feeder lines subject to } \\
\text { Swift County authority. }\end{array}$ \\
\hline Lighting & $\begin{array}{l}\text { Lighting, including lighting intensity and strobe frequency, shall adhere } \\
\text { to but not exceed requirements established by Federal Aviation } \\
\text { Administration permits and regulations. Red strobe lights are preferred } \\
\text { for nighttime illumination to reduce impacts on migrating birds. Red } \\
\text { pulsating incandescent lights should be avoided. }\end{array}$ \\
\hline Equipment & No equipment standards \\
\hline $\begin{array}{l}\text { Appearance, Color, } \\
\text { and Finish }\end{array}$ & $\begin{array}{l}\text { All wind turbines and towers that are part of large WECS shall be white, } \\
\text { grey, or another non-obtrusive color. Blades may be black to facilitate } \\
\text { de-icing. Finishes shall be matte or non-reflective. International blade } \\
\text { markings are accepted. }\end{array}$ \\
\hline Signs & $\begin{array}{l}\text { 1) For all large WECS, a sign or signs shall be posted on the tower, } \\
\text { transformer, and substation warning of high voltage. (Signs with } \\
\text { emergency contact information shall also be posted on the turbine or at } \\
\text { another suitable point.) } \\
\text { 2) The manufacturer's or owner's company name and/or logo may be } \\
\text { placed on the nacelles of the WECS. }\end{array}$ \\
\hline Permits Required & Land Use Permit, Conditional Use Permit \\
\hline
\end{tabular}




\begin{tabular}{|c|c|}
\hline $\begin{array}{l}\text { Restoration } \\
\text { Requirement }\end{array}$ & $\begin{array}{l}\text { All WECS and accessory facilities shall be removed to } 4 \text { feet below } \\
\text { ground level within } 90 \text { days of the discontinuation of use. WECS also } \\
\text { require a decommissioning plan. }\end{array}$ \\
\hline Signal Interference & $\begin{array}{l}\text { The applicant shall minimize or mitigate interference with } \\
\text { electromagnetic communications such as radio, telephone, microwaves, } \\
\text { or television signals caused by WECS. The applicant shall notify all } \\
\text { communication tower operators within } 5 \text { miles of the proposed WECS } \\
\text { location upon application to the county for permits. No WECS shall be } \\
\text { constructed as to interfere with County or Minnesota Department of } \\
\text { Transportation microwave transmissions. }\end{array}$ \\
\hline Noise & All WECS shall comply with Minnesota Rules 7030 governing noise. \\
\hline Shadow Flicker & No shadow flicker standards \\
\hline Link & $\begin{array}{l}\text { http://www.swiftcounty.com/vertical/Sites/\%7BCB23E7E9-8CD6- } \\
\text { 437F-AE42-22084996955A\%7D/uploads/\%7B316C62D9-5A0C-436F- } \\
\text { BECE-6B8A6B7CA644\%7D.PDF }\end{array}$ \\
\hline
\end{tabular}




\begin{tabular}{|c|c|}
\hline \multicolumn{2}{|c|}{$\begin{array}{l}\text { New York } \\
\text { Hamlin, New York }\end{array}$} \\
\hline Zoning Areas & Wind Energy Overlay District \\
\hline Where Turbines are & 1) A Wind Energy Overlay District may be created in the Residential- \\
\hline Allowed & Very Low zoning district only. \\
\hline & 2) Initial requests for Wind Energy Overlay Districts shall be submitted \\
\hline & with applications for WECS Special Use Permits. No Wind Energy \\
\hline & $\begin{array}{l}\text { Overlay District may be initially created without specific requests for } \\
\text { WECS. }\end{array}$ \\
\hline & 3) Once a Wind Energy Overlay District has been created, new WECS \\
\hline & $\begin{array}{l}\text { or accessory structures or facilities may be added in that district by grant } \\
\text { of a Special Use Permit pursuant to the requirements of this section. }\end{array}$ \\
\hline Set Backs & $\begin{array}{l}\text { WECS shall be set back from site boundaries, measured from the center } \\
\text { of the WECS, a minimum distance of: }\end{array}$ \\
\hline & 1) 600 feet from the nearest site boundary property line, except the \\
\hline & $\begin{array}{l}\text { setback shall be } 500 \text { feet where the boundary is with state, county, town, } \\
\text { or village-owned property }\end{array}$ \\
\hline & 2) 600 feet from the nearest public road \\
\hline & $\begin{array}{l}\text { 3) 1,200 feet from the nearest off-site residence existing at the time of } \\
\text { application, measured from the exterior of such residence }\end{array}$ \\
\hline & 4) 100 feet from state-identified wetlands. This distance may be \\
\hline & adjusted to be greater or lesser at the discretion of the reviewing body, \\
\hline & $\begin{array}{l}\text { based on topography, land cover, land uses, and other factors that } \\
\text { influence the flight patterns of resident birds. }\end{array}$ \\
\hline & $\begin{array}{l}\text { Other WECS structures and improvements shall comply with the } \\
\text { underlying zoning district regulations. }\end{array}$ \\
\hline $\begin{array}{l}\text { Spacing and } \\
\text { Density }\end{array}$ & No spacing and density standards \\
\hline Height & The maximum total height of any turbine shall be 400 feet. \\
\hline Clearance & $\begin{array}{l}\text { The minimum distance between the ground and any part of the rotor or } \\
\text { blade system shall be } 20 \text { feet. }\end{array}$ \\
\hline Access & $\begin{array}{l}\text { 1) If the property owner submits a written request that fencing be } \\
\text { required, a 6-foot fence with a locking portal shall be required to } \\
\text { enclose each tower or group of towers. The color and type of fencing for } \\
\text { each WECS installation shall be determined on the basis of individual } \\
\text { applications as safety needs dictate. } \\
\text { 2) No climbing pegs or tower ladders shall be located closer than } 12 \text { feet } \\
\text { to the ground level at the base of the structure for freestanding single } \\
\text { poles. } \\
\text { 3) WECS shall be designed to prevent unauthorized external access to } \\
\text { electrical and mechanical components and shall have access doors that } \\
\text { are kept securely locked. } \\
\text { 4) All access roads shall be gated and locked. }\end{array}$ \\
\hline Electrical Wires & $\begin{array}{l}\text { All power transmission lines from the tower to any other building or } \\
\text { other structure shall be located underground to the maximum extent } \\
\text { practical. }\end{array}$ \\
\hline
\end{tabular}




\begin{tabular}{|l|l|}
\hline Lighting & $\begin{array}{l}\text { No tower shall be lit except to comply with Federal Aviation } \\
\text { Administration requirements. Minimum-security lighting for ground- } \\
\text { level facilities shall be allowed as approved on the site plan. Security } \\
\text { lighting shall be designed to minimize light pollution, including the use } \\
\text { of light hoods, low-glare fixtures, and directing lights at the ground. }\end{array}$ \\
\hline Equipment & No equipment standards \\
\hline $\begin{array}{l}\text { Appearance, Color, } \\
\text { and Finish }\end{array}$ & $\begin{array}{l}\text { All structures in a project shall be finished in a single, non-reflective, } \\
\text { matte color or a camouflage scheme. Individual WECS within a wind } \\
\text { energy overlay zone shall be constructed using wind turbines whose } \\
\text { appearance, with respect to one another, is similar within and } \\
\text { throughout the zone to provide reasonable uniformity in overall size, } \\
\text { geometry, and rotational speeds. }\end{array}$ \\
\hline Signs & $\begin{array}{l}\text { 1) No advertising signs are allowed on any part of the WECS, including } \\
\text { fencing and support structures. } \\
\text { 2) No lettering, company insignia, advertising, or graphics shall be on } \\
\text { any part of the tower, hub, or blades. } \\
\text { 3) Appropriate warning signs shall be posted. At least one sign shall be } \\
\text { posted at the base of the tower warning of electrical shock or high } \\
\text { voltage. A sign shall be posted on the entry area of the fence around } \\
\text { each tower or group of towers and any building (or on the tower or } \\
\text { building if there is no fence) containing emergency contact information, } \\
\text { including a local telephone number with 24-hour, 7-days-a-week } \\
\text { coverage. The town board may require additional signs based on safety } \\
\text { needs. }\end{array}$ \\
\hline Special Use Permit \\
\hline Permits Required
\end{tabular}




\begin{tabular}{|c|c|}
\hline Noise & $\begin{array}{l}\text { 1) The statistical sound-pressure level generated by WECS shall not } \\
\text { exceed a } 6 \mathrm{dBA} \text { increase over ambient measured at the closest exterior } \\
\text { wall of any residence existing at the time of completing the SEQRA } \\
\text { review of the application. Independent certification shall be provided } \\
\text { before and after construction demonstrating compliance with this } \\
\text { requirement. } \\
\text { 2) In the event audible noise due to WECS operations contains a steady } \\
\text { pure tone, such as a whine, screech, or hum, the standards for audible } \\
\text { noise set forth in subparagraph 1) of this subsection shall be reduced by } \\
5 \text { dBA. A pure tone is defined to exist if one-third octave band sound } \\
\text { pressure level in the band, including the tone, exceed the arithmetic } \\
\text { average of the sound pressure levels of the two contiguous one third } \\
\text { octave bands by } 5 \text { dBA for center frequencies of } 500 \mathrm{~Hz} \text { and above, by } \\
8 \text { dBA for center frequencies between } 160 \text { Hz and } 400 \mathrm{~Hz} \text {, or by } 15 \\
\text { dBA for center frequencies less than or equal to } 125 \mathrm{~Hz} \text {. } \\
3 \text { ) The ambient noise level shall be expressed in terms of the highest } \\
\text { whole number sound pressure level in dBA, which is exceeded for more } \\
\text { than } 5 \text { minutes per hour. Ambient noise levels shall be measured at the } \\
\text { exterior of potentially affected existing residences. Ambient noise level } \\
\text { measurement techniques shall employ all practical means of reducing } \\
\text { the effect of wind-generated noise at the microphone. Ambient-noise- } \\
\text { level measurements may be performed when wind velocities at the } \\
\text { proposed project site are sufficient to allow wind turbine operation, } \\
\text { provided that the wind velocity does not exceed } 30 \text { mph at the ambient } \\
\text { noise measurement location. } \\
4 \text { ) Any noise falling between two whole decibels shall be the lower of } \\
\text { the two. }\end{array}$ \\
\hline Shadow Flicker & No shadow flicker standards \\
\hline Link & http://www.hamlinny.org/pdf/wind-tower/Wind Energy_LL-2008.pdf \\
\hline
\end{tabular}


Pennsylvania

Antis Township, Pennsylvania

\begin{tabular}{|c|c|}
\hline $\begin{array}{l}\text { Zoning Areas } \\
\text { Where Turbines are } \\
\text { Allowed }\end{array}$ & No specified zoning areas \\
\hline Set Backs & $\begin{array}{l}\text { 1) Civil structures: Each wind turbine generator shall be set back from } \\
\text { the nearest existing (at the time of the building permit issuance) school, } \\
\text { hospital, church, or public library a distance of no less than } 2,500 \text { feet. } \\
\text { 2) Participating residences: For existing (at the time of the notice from } \\
\text { the building code enforcement officer that no building permit is } \\
\text { required) participating primary occupied residences, the setback } \\
\text { distance from a wind turbine generator shall be at least } 1,000 \text { feet. In the } \\
\text { event a lesser distance is desired, the developer/permitee shall request a } \\
\text { waiver to this provision pursuant to the requirements of this ordinance. } \\
\text { In no event shall the setback distance be less than } 1.1 \text { times the total } \\
\text { height of the wind turbine generator. } \\
\text { 3) Non-participating residences: For existing (at the time of the building } \\
\text { permit issuance or notice from the building code enforcement officer } \\
\text { that no building permit is required) non-participating primary occupied } \\
\text { residences, the setback distance from a wind turbine generator shall be } \\
\text { at least } 2,500 \text { feet. } \\
\text { 4) Property lines: Each wind turbine generator shall be set back from the } \\
\text { nearest property line a distance of no less than } 1,000 \text { feet. } \\
\text { 5) Public roads: Each wind turbine generator shall be set back from the } \\
\text { nearest public road a distance of no less than } 1,000 \text { feet, determined at } \\
\text { the nearest boundary of the right-of-way for such public road. Unless } \\
\text { conclusive evidence exists to the contrary, the public road right-of-way } \\
\text { is presumed to be } 66 \text { feet. } \\
\text { 6) Communication and electric lines: Each wind turbine generator shall } \\
\text { be set back from the nearest above-ground public electric power line or } \\
\text { public telephone line a distance of no less than } 1,000 \text { feet. } \\
\text { 7) Natural resources and historical sites and structures: Each wind } \\
\text { turbine generator shall be set back a distance of no less than } 2,500 \text { feet } \\
\text { from the nearest existing critical and irreplaceable natural and cultural } \\
\text { resource areas of the township. }\end{array}$ \\
\hline $\begin{array}{l}\text { Spacing and } \\
\text { Density }\end{array}$ & No spacing and density standards \\
\hline Height & $\begin{array}{l}\text { No height standards, but "Developer/permitee shall install wind turbine } \\
\text { generators of } 2 \text { megawatts nameplate capacity each unless otherwise } \\
\text { agreed to by the parties, which comply with all terms and provisions in } \\
\text { this agreement." }\end{array}$ \\
\hline Clearance & No clearance standards \\
\hline Access & $\begin{array}{l}\text { 1) The outside of the wind turbine generator towers shall not be } \\
\text { climbable. } \\
\text { 2) All access doors to the towers and electrical equipment shall be } \\
\text { locked. }\end{array}$ \\
\hline
\end{tabular}




\begin{tabular}{|l|l|}
\hline Electrical Wires & $\begin{array}{l}\text { All wiring between the wind turbine generators and the substation shall } \\
\text { be underground to the extent practicable. }\end{array}$ \\
\hline Lighting & $\begin{array}{l}\text { The wind turbine generators shall not be artificially illuminated except } \\
\text { as required by the Federal Aviation Administration or any other } \\
\text { applicable authority. If lighting is required, the lighting alternatives and } \\
\text { design will seek to minimize the disturbance to the surrounding views. }\end{array}$ \\
\hline Equipment & No equipment standards \\
\hline $\begin{array}{l}\text { Appearance, Color, } \\
\text { and Finish }\end{array}$ & $\begin{array}{l}\text { The towers and generators of the wind turbine generators shall have a } \\
\text { non-reflective, painted steel finish in a neutral color, subject to any } \\
\text { applicable standards of the Federal Aviation Administration or other } \\
\text { regulatory requirements. The blades of the wind turbine generators are } \\
\text { not covered by this section. }\end{array}$ \\
\hline Signs & $\begin{array}{l}\text { 1) No advertising material or signage other than warning, equipment } \\
\text { information, or indicia of ownership shall be allowed on the wind } \\
\text { turbine generators. This prohibition shall include the attachment of any } \\
\text { flag, decorative sign, streamers, pennants, ribbons, spinners, or waving, } \\
\text { fluttering, or revolving devices, but not including weather devices. } \\
\text { 2) Appropriate and clearly visible warning signage shall be placed on } \\
\text { each tower, all electrical equipment, and all entrances. }\end{array}$ \\
\hline Permits Required & $\begin{array}{l}\text { Building Permit: fee is } \$ 1,500 \text { per proposed MW for each wind turbine } \\
\text { generator }\end{array}$ \\
\hline Restoration \\
Requirement
\end{tabular}




\section{South Dakota}

Brookings County, South Dakota

\begin{tabular}{|c|c|}
\hline $\begin{array}{l}\text { Zoning Areas } \\
\text { Where Turbines are } \\
\text { Allowed }\end{array}$ & No zoning standards \\
\hline Set Backs & $\begin{array}{l}\text { 1) Distance from existing off-site residences, business, and public } \\
\text { buildings shall be } 1,000 \text { feet. Distance from on-site or lessor's residence } \\
\text { shall be } 1,000 \text { feet. } \\
\text { 2) Distance from right-of-way of public roads shall be } 500 \text { feet or } 1.1 \\
\text { times the height of the wind turbines (depending on which is greater), } \\
\text { measured from the ground surface to the tip of the blade when in a fully } \\
\text { vertical position. } \\
\text { 3) Distance from any property line shall be } 500 \text { feet or } 1.1 \text { times the } \\
\text { height of the wind turbine (depending on which is greater), measured } \\
\text { from the ground surface to the tip of the blade in a fully vertical position } \\
\text { unless a wind easement has been obtained from the adjoining property } \\
\text { owner. }\end{array}$ \\
\hline $\begin{array}{l}\text { Spacing and } \\
\text { Density }\end{array}$ & $\begin{array}{l}\text { The turbines shall be spaced no closer than three rotor diameters } \\
\text { measurement of blades tip to tip. If required during final micrositing of } \\
\text { the turbines to account for topographic conditions, up to } 10 \% \text { of the } \\
\text { towers may be sited closer than the above spacing, but the permittees } \\
\text { shall minimize the need to site the turbines closer. }\end{array}$ \\
\hline Height & No specified height standards \\
\hline Clearance & $\begin{array}{l}\text { The minimum height of blade tips, measured from ground surface when } \\
\text { a blade is in fully vertical position, shall be } 25 \text { feet. }\end{array}$ \\
\hline Access & No access standards \\
\hline Electrical Wires & $\begin{array}{l}\text { 1) Electrical cables: The permittees shall place electrical lines, known as } \\
\text { collectors, and communication cables underground when located on } \\
\text { private property. Collectors and cables shall also be placed within or } \\
\text { immediately adjacent to the land necessary for turbine access roads } \\
\text { unless otherwise negotiated with the affected landowner. } \\
\text { 2) Feeder lines: The permittees shall place overhead electric lines, } \\
\text { known as feeders, on public right-of-way if a public right-of-way exists. } \\
\text { Route changes may be made as long as feeders remain on public rights- } \\
\text { of-way and approval has been obtained from the government unit } \\
\text { responsible for the affected right-of-way. If no public right-of-way } \\
\text { exists, the permittees may place feeders on private property. When } \\
\text { placing feeders on private property, the permittees shall place the feeder } \\
\text { in accordance with the easement negotiated with the affected landowner. } \\
\text { The permittees shall submit the site plan and engineering drawings for } \\
\text { the feeder lines before commencing construction. }\end{array}$ \\
\hline Lighting & $\begin{array}{l}\text { Towers shall be marked as required by the Federal Aviation } \\
\text { Administration. There shall be no lights on the tower other than what is } \\
\text { required by the FAA. This restriction shall not apply to infrared heating } \\
\text { devices used to protect the monitoring equipment. }\end{array}$ \\
\hline Equipmen & No equipment standards \\
\hline
\end{tabular}




\begin{tabular}{|l|l|}
\hline $\begin{array}{l}\text { Appearance, Color, } \\
\text { and Finish }\end{array}$ & The finish of the exterior surface shall be non-reflective and non-gloss. \\
\hline Signs & No sign standards \\
\hline Permits Required & Permit required (type not specified) \\
\hline Restoration & $\begin{array}{l}\text { Upon expiration of this permit, or upon earlier termination of systems } \\
\text { operation, the permittees shall have the obligation to dismantle and } \\
\text { remove from the site all towers, turbine generators, transformers, } \\
\text { overhead and underground cables, foundations, building, and ancillary } \\
\text { equipment to a depth of } 4 \text { feet. To the extent possible, the permittees } \\
\text { shall restore and reclaim the site to its pre-project topography and } \\
\text { topsoil quality. All access roads shall be removed unless written } \\
\text { approval is given by the affected landowner requesting that one or more } \\
\text { roads, or portions thereof, be retained. Any agreement for removal to a } \\
\text { lesser depth or for no removal shall be recorded with the County Zoning } \\
\text { Office and shall show the locations of all such foundations. All such } \\
\text { agreements between the permittees and the affected landowner shall be } \\
\text { submitted to the County Zoning Office prior to completion of } \\
\text { restoration activities. The site shall be restored in accordance with the } \\
\text { requirements of this condition within 18 months after expiration. }\end{array}$ \\
\hline Signal Interference & $\begin{array}{l}\text { The permittees shall not operate the WECS so as to cause microwave, } \\
\text { television, radio, or navigation interference contrary to Federal } \\
\text { Communication Commission regulations or other law. In the event such } \\
\text { interference is caused by the WECS or its operations, the permittees } \\
\text { shall take measures necessary to correct the problem. }\end{array}$ \\
\hline Noise & $\begin{array}{l}\text { Noise level shall not exceed 50 dBA, including constructive interference } \\
\text { at existing off-site residences, businesses, and public buildings. }\end{array}$ \\
\hline Shadow Flicker & No shadow flicker standards \\
\hline Link & $\begin{array}{l}\text { http://www.brookingscountysd.gov/zoning/Completed\%20Zoning\%20 } \\
\text { Ordinance-11-27-07 w \%202008-04update.pdf }\end{array}$ \\
\hline
\end{tabular}


Wisconsin

Buffalo County, Wisconsin

\begin{tabular}{|c|c|}
\hline $\begin{array}{l}\text { Zoning Areas } \\
\text { Where Turbines are } \\
\text { Allowed }\end{array}$ & Agricultural \\
\hline Set Backs & $\begin{array}{l}\text { 1) Blufflines: Each wind turbine shall be set back from all blufflines. } \\
\text { 2) Habitable structures: Each wind turbine shall be set back from a } \\
\text { habitable structure a distance of } 50 \text { feet, plus the height of the turbine } \\
\text { from ground level to the tip of the blade at maximum height. } \\
\text { 3) Property lines: Each wind turbine shall be set back from the nearest } \\
\text { public road right-of-way a distance of } 50 \text { feet, plus the height of the } \\
\text { wind turbine from ground level to the tip of the blade at maximum } \\
\text { height. } \\
\text { 4) Communication and electrical power lines: Each wind turbine shall } \\
\text { be set back from the nearest above-ground electric power line or } \\
\text { telephone line a distance of } 50 \text { feet, plus the height of the tower as } \\
\text { determined from the existing line unless appropriate easements are } \\
\text { obtained from the power or telephone company whose lines would be } \\
\text { affected and recorded at Buffalo County Register of Deeds. }\end{array}$ \\
\hline $\begin{array}{l}\text { Spacing and } \\
\text { Density }\end{array}$ & No spacing and density standards \\
\hline Height & No height standards \\
\hline Clearance & 50 feet \\
\hline Access & $\begin{array}{l}\text { 1) Wind turbine towers shall not be climbable up to } 15 \text { feet above } \\
\text { ground level. } \\
\text { 2) All access doors to wind turbine towers and electrical equipment } \\
\text { shall be lockable. }\end{array}$ \\
\hline Electrical Wires & $\begin{array}{l}\text { 1) All wiring between wind turbines and the WECS substation shall be } \\
\text { underground. } \\
\text { 2) Electrical controls and control wiring and power lines shall be } \\
\text { wireless or not above ground except where wind farm collector wiring is } \\
\text { brought together for connection to the transmission or distribution } \\
\text { network, adjacent to that network. }\end{array}$ \\
\hline Lighting & $\begin{array}{l}\text { WECS shall not be artificially lit, except to the extent required by the } \\
\text { Federal Aviation Administration or other applicable authority. }\end{array}$ \\
\hline Equipment & No equipment standards \\
\hline $\begin{array}{l}\text { Appearance, Color, } \\
\text { and Finish }\end{array}$ & $\begin{array}{l}\text { 1) Wind turbines shall be painted a non-reflective, non-obtrusive color. } \\
\text { 2) At WECS sites, the design of the buildings and related structures } \\
\text { shall, to the extent reasonably possible, use materials, colors, textures, } \\
\text { screening, and landscaping that will blend the WECS into the natural } \\
\text { setting and the existing environment. }\end{array}$ \\
\hline Signs & $\begin{array}{l}\text { 1) Wind turbines shall not be used to display any advertising except for } \\
\text { reasonable identification for the manufacturer or operator of the WECS. } \\
\text { 2) Appropriate warning signs shall be placed on wind turbine towers, } \\
\text { electrical equipment, and WECS entrances. }\end{array}$ \\
\hline
\end{tabular}




\begin{tabular}{|c|c|}
\hline Permits Required & $\begin{array}{l}\text { Conditional Use Permit, Wind Energy Conversion System Zoning } \\
\text { Permit }\end{array}$ \\
\hline $\begin{array}{l}\text { Restoration } \\
\text { Requirement }\end{array}$ & $\begin{array}{l}\text { No restoration requirements, but a plan for abandonment must } \\
\text { accompany the application for a conditional use permit. }\end{array}$ \\
\hline Signal Interference & $\begin{array}{l}\text { The applicant shall take reasonable steps to minimize interference with } \\
\text { electromagnetic communications, such as radio, telephone, or television } \\
\text { signals caused by WECS. }\end{array}$ \\
\hline Noise & 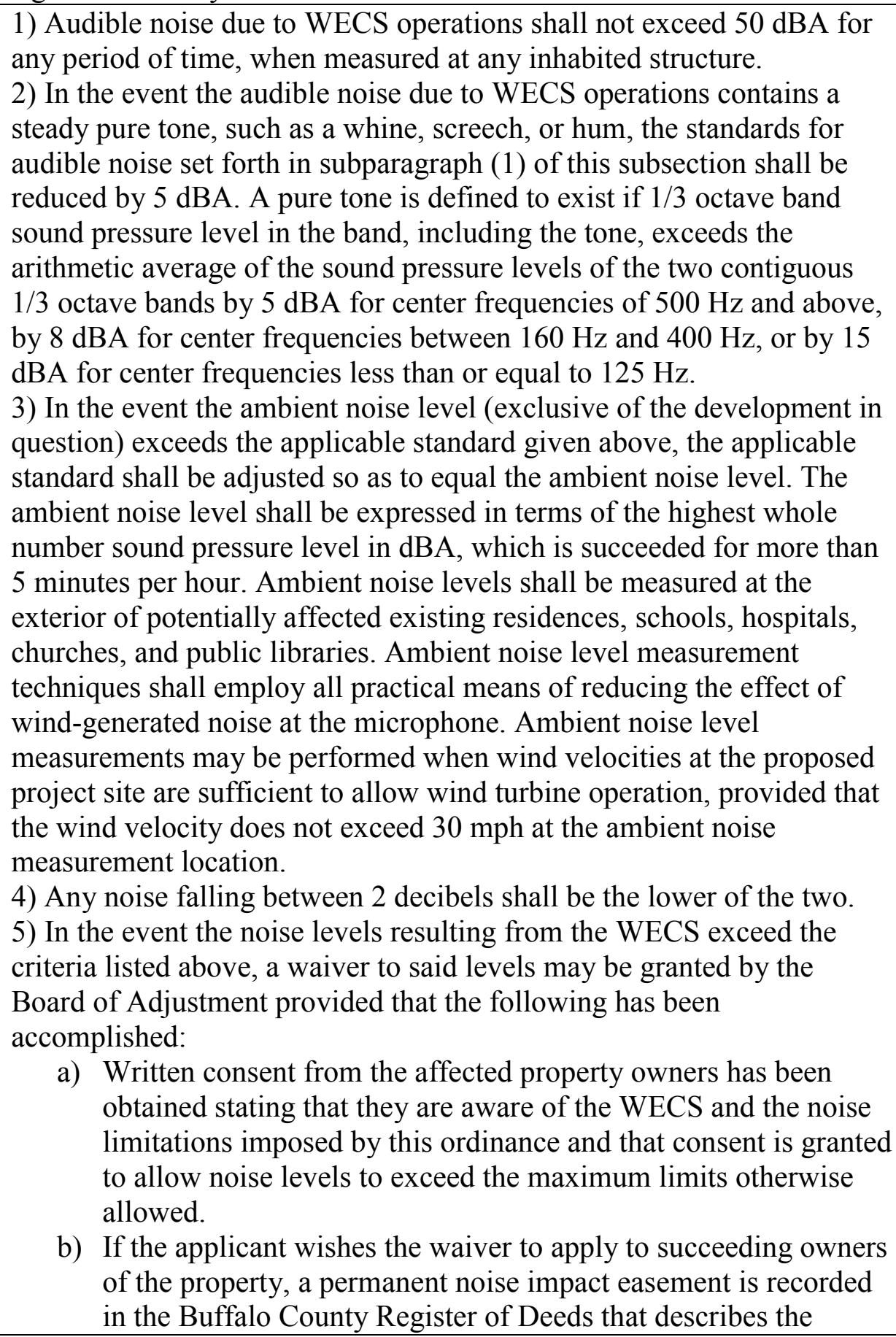 \\
\hline
\end{tabular}




\begin{tabular}{|l|l|}
\hline & \multicolumn{1}{|c|}{$\begin{array}{c}\text { benefited and burdened properties and that advises all } \\
\text { subsequent owners of the burdened properties that noise levels in } \\
\text { excess of those permitted by this ordinance may exist on or at } \\
\text { the burdened property. }\end{array}$} \\
\hline Shadow Flicker & $\begin{array}{l}\text { No shadow flicker standards, but a "document including an } \\
\text { accompanying aerial photo if necessary, showing the shadow flicker } \\
\text { projection" must accompany the application for a conditional use } \\
\text { permit. }\end{array}$ \\
\hline Link & $\begin{array}{l}\text { http://www.buffalocounty.com/County\%20Board/Ordinances/Full\%20 } \\
\text { Wind\%20Energy\%20Facility\%20Ordinance.pdf }\end{array}$ \\
\hline
\end{tabular}




\section{Door County, Wisconsin}

\begin{tabular}{|c|c|}
\hline $\begin{array}{l}\text { Zoning Areas } \\
\text { Where Turbines are } \\
\text { Allowed }\end{array}$ & $\begin{array}{l}\text { WECS may only be constructed in areas that are designated as } \\
\text { Exclusive Agricultural, Prime Agricultural, General Agricultural, } \\
\text { Countryside and Heartland-10 }\end{array}$ \\
\hline Set Backs & $\begin{array}{l}\text { 1) Inhabited structures: WECS shall be set back from the nearest } \\
\text { residence, school, hospital, church, public library, and/or places of } \\
\text { frequent public gathering a distance of no less than the greater of } \\
\text { (A) two times its total height or (B) } 1,000 \text { feet. } \\
\text { 2) Property lines: WECS shall be set back from the nearest property line } \\
\text { the distance of the fall zone, as certified by a professional engineer, plus } \\
\text { 10\% of its total height, or a distance no less than } 1.1 \text { times its total } \\
\text { height, whichever is greater. } \\
\text { 3) Public and private roads: WECS shall be set back from the nearest } \\
\text { public or private road or other right of way the distance of the fall zone } \\
\text { as certified by a professional engineer plus } 10 \% \text { of its total height, or no } \\
\text { less than } 1.1 \text { times its total height, whichever is greater. This setback } \\
\text { shall be measured from the nearest boundary of the underlying right-of-way. } \\
\text { 4) Telephone and electrical lines: WECS shall be set back from above- } \\
\text { ground electrical power lines, telephone lines, or unimproved easements } \\
\text { for the same distance of the fall zone, as certified by a professional } \\
\text { engineer, plus } 10 \% \text { of its total height, or a distance no less than } 1.1 \\
\text { times its total height, whichever is greater. Setbacks from existing } \\
\text { power or telephone lines shall be measured from the lines. If no power } \\
\text { line or telephone line exists within a utility easement, the setback shall } \\
\text { be measured from the nearest utility easement right-of-way boundary. } \\
\text { 5) Critical Communications Systems: } \\
\text { a) WECS shall be set back a distance no less than } 1 / 2 \text { mile to existing } \\
\text { critical communication structures, unless the applicant/permit } \\
\text { holder/owner has submitted a plan to provide a replacement signal that } \\
\text { would restore reception to at least the level present before operation of } \\
\text { the wind energy system in the event of signal interference; and } \\
\text { b) WECS shall be set back a distance no less than } 500 \text { feet from either } \\
\text { side of the line of sight of an existing critical microwave } \\
\text { communications link, unless the applicant/permit holder/owner has } \\
\text { submitted a plan to provide a replacement signal that would restore } \\
\text { reception to at least the level present before operation of the wind } \\
\text { energy system in the event of signal interference. }\end{array}$ \\
\hline $\begin{array}{l}\text { Spacing and } \\
\text { Density }\end{array}$ & No spacing or density standards \\
\hline Height & No height restrictions \\
\hline Clearance & $\begin{array}{l}\text { The blade tip of any wind turbine shall, at its lowest point, have ground } \\
\text { clearance of no less than } 75 \text { feet. }\end{array}$ \\
\hline Access & $\begin{array}{l}\text { Any wind turbine and/or accessory structure shall not be climbable up to } \\
15 \text { feet above ground level. WECS sites shall be secure (e.g., fence, } \\
\text { locked gate, and locked doors to any wind turbine and/or accessory } \\
\text { structure). }\end{array}$ \\
\hline
\end{tabular}




\begin{tabular}{|c|c|}
\hline Electrical Wires & $\begin{array}{l}\text { Electrical controls and control wiring shall be wireless or below ground. } \\
\text { WECS collector wiring connected to the transmission or distribution } \\
\text { network, adjacent to that network, may be above ground. }\end{array}$ \\
\hline Lighting & $\begin{array}{l}\text { WECS shall not be artificially lighted, except to the minimum extent } \\
\text { required by the Federal Aviation Administration or other applicable } \\
\text { authority. }\end{array}$ \\
\hline Equipment & No equipment standards \\
\hline $\begin{array}{l}\text { Appearance, Color, } \\
\text { and Finish }\end{array}$ & Wind turbines shall be painted a non-reflective, non-obtrusive color. \\
\hline Signs & $\begin{array}{l}\text { Wind turbines shall not be used to display any advertising except for } \\
\text { reasonable identification of the manufacturer or operator of the WECS } \\
\text { and the utility procuring the power. }\end{array}$ \\
\hline Permits Required & WECS Siting Permit \\
\hline $\begin{array}{l}\text { Restoration } \\
\text { Requirement }\end{array}$ & $\begin{array}{l}\text { 1) All WECS components shall be removed from the property. } \\
\text { 2) All items in outdoor storage will be removed from the property. } \\
\text { 3) All building foundations, tower pads, and buried electrical } \\
\text { improvements shall be removed to a depth of } 4 \text { feet below the ground } \\
\text { surface. } \\
\text { 4) All excavated areas shall be filled in and made level with ground } \\
\text { surface surrounding the excavated area with unconsolidated soil } \\
\text { material, at least the top } 4 \text { inches of which shall be screened topsoil. } \\
\text { 5) A post-decommissioning storm water runoff plan shall be } \\
\text { implemented. }\end{array}$ \\
\hline Signal Interference & $\begin{array}{l}\text { The applicant/permit holder/owner shall conduct a study on critical } \\
\text { communications per s.3.02(2)(c). Not sooner than } 12 \text { months and not } \\
\text { later than } 18 \text { months of the date when the project becomes fully } \\
\text { operational, or at any time upon receipt of a verified complaint of signal } \\
\text { interference, the applicant/permit holder/owner shall also submit to the } \\
\text { Zoning Administrator a critical communications systems interference } \\
\text { study prepared by a registered professional engineer (qualified by } \\
\text { training, education, and experience to conduct such a study) certifying } \\
\text { that the WECS do not and will not interfere with critical } \\
\text { communications. If it is determined at any time that the WECS interfere } \\
\text { with critical communications, the applicant/permit holder/owner shall } \\
\text { implement and maintain any corrective measure needed to insure that } \\
\text { the WECS will not interfere with critical communications. }\end{array}$ \\
\hline Noise & $\begin{array}{l}\text { 1) Audible sound due to WECS operations shall not exceed (50) dBA } \\
\text { for any period of time when measured at the property line of any } \\
\text { residence, school, hospital, church public library, or place of frequent } \\
\text { public gathering existing on the date of issuance of any WECS Siting } \\
\text { Permit, or any proposed structure which meets requirements of s. } \\
\text { 3.04(1)(b). } \\
\text { 2) Audible sound due to WECS operations shall not exceed } 45 \mathrm{dBA} \\
\text { inside any occupied structure existing on the date of issuance of any } \\
\text { WECS Siting Permit. }\end{array}$ \\
\hline
\end{tabular}




\begin{tabular}{|c|c|}
\hline & $\begin{array}{l}\text { 3) In the event audible sound due to operations contains a steady pure } \\
\text { tone, such as a whine, screech, or hum, such sound shall not exceed } 45 \\
\text { dBA for any period of time when measured at the property line of any } \\
\text { residence, school, hospital, church, public library, or place of frequent } \\
\text { public gathering existing on the date of issuance of any WECS Siting } \\
\text { Permit, or any proposed structure which meets requirements of s. } \\
\text { 3.04(1)(b). } \\
\text { 4) If the ambient sound level causes WECS that would otherwise be } \\
\text { compliant to exceed the applicable standards given above, the applicable } \\
\text { standards shall be adjusted to the ambient sound level. } \\
\text { 5) In the event audible sound due to operations shall exceed the audible } \\
\text { sound standards listed above, a waiver to said standards may be granted } \\
\text { provided that the following has been accomplished: } \\
\text { a) Written consent from the affected property owners has been } \\
\text { obtained stating that they are aware of the WECS and the } \\
\text { audible sound standards imposed by this ordinance, and that } \\
\text { consent is granted to allow sound levels to exceed the audible } \\
\text { sound standards otherwise allowed; and } \\
\text { b) The applicant/permit holder/owner shall record a permanent } \\
\text { sound impact easement with the Door County Register of Deeds, } \\
\text { which describes the burdened properties and which advises all } \\
\text { subsequent owners of the burdened property that sound levels in } \\
\text { excess of audible sound standards permitted by this ordinance } \\
\text { may exist on or at the burdened property. } \\
\text { 6) The applicant/permit holder/owner shall submit to the Zoning } \\
\text { Administrator a sound study prepared by a registered professional } \\
\text { engineer (qualified by training, education, and experience to conduct } \\
\text { such a study) certifying compliance with the sound regulations set forth } \\
\text { herein no sooner than 12 months and no later than 18 months of the date } \\
\text { when the project becomes fully operational, or at any time upon receipt } \\
\text { of a verified sound complaint. If at any time it is determined that the } \\
\text { maximum sound levels set forth herein are exceeded, the } \\
\text { applicant/permit holder/owner shall immediately implement any and all } \\
\text { measures necessary to permanently reduce sound levels to compliant } \\
\text { levels. }\end{array}$ \\
\hline Shadow Flicker & $\begin{array}{l}\text { The applicant/permit holder/owner shall conduct a study on shadow } \\
\text { flicker and blade glint per s. } 3.02(2)(\text { b). Not sooner than } 12 \text { months and } \\
\text { not later than } 18 \text { months of the date when the project becomes fully } \\
\text { operational, or at anytime upon receipt of a verified complaint of } \\
\text { shadow flicker and/or blade glint, the applicant/permit holder/owner } \\
\text { shall also submit to the Zoning Administrator a shadow flicker and } \\
\text { blade glint study prepared by a registered professional engineer } \\
\text { (qualified by training, education, and experience to conduct such a } \\
\text { study) certifying that shadow flicker and blade glint present no } \\
\text { deleterious effects for any occupied structure located within a 1-mile } \\
\text { radius of any wind turbine. If it is determined that shadow flicker and/or }\end{array}$ \\
\hline
\end{tabular}




\begin{tabular}{|l|l|}
\hline & $\begin{array}{l}\text { blade glint exists at any occupied structures, the applicant/permit } \\
\text { holder/owner shall implement and maintain all necessary remedial } \\
\text { measures. }\end{array}$ \\
\hline Link & $\underline{\text { http://www.co.door.wi.gov/county/app/docs/door/200806120844493880 }}$ \\
\hline
\end{tabular}




\section{Manitowoc, Wisconsin}

\begin{tabular}{|c|c|}
\hline $\begin{array}{l}\text { Zoning Areas } \\
\text { Where Turbines are } \\
\text { Allowed }\end{array}$ & $\begin{array}{l}\text { May be located in areas that are zoned A-3 Agriculture or PA-Prime } \\
\text { Agricultural. May not be located within } 1 / 4-\text { mile of any area that is zoned } \\
\text { C1-Conservancy or NA-Natural Area or within } 1 / 4-\text { mile of any state or } \\
\text { county forest, hunting area, lake access, natural area, or park. }\end{array}$ \\
\hline Set Backs & $\begin{array}{l}\text { 1) At least } 1.1 \text { times the total height of the large wind system from the } \\
\text { property line of a participating property } \\
\text { 2) At least } 1,000 \text { feet from the property line of a nonparticipating } \\
\text { property unless the owner of the nonparticipating property grants an } \\
\text { easement for a lesser setback. The easement must be recorded with the } \\
\text { Register of Deeds and may not provide for a setback that is less than } 1.1 \\
\text { times the total height of the large wind system. } \\
\text { 3) At least } 1.1 \text { times the total height of the large wind system or } 500 \text { feet, } \\
\text { whichever is greater, from any public road or power line right-of-way }\end{array}$ \\
\hline $\begin{array}{l}\text { Spacing and } \\
\text { Density }\end{array}$ & $\begin{array}{l}\text { A wind tower must be separated from every other wind tower by a } \\
\text { sufficient distance so that it does not interfere with the other wind tower. }\end{array}$ \\
\hline Height & The total height of a wind energy system must be 500 feet or less. \\
\hline Clearance & $\begin{array}{l}\text { The vertical distance from ground level to the tip of a wind turbine } \\
\text { blade when the blade is at its lowest point must be at least } 75 \text { feet. }\end{array}$ \\
\hline Access & $\begin{array}{l}\text { A wind tower, including any climbing aids, must be secured against } \\
\text { unauthorized access by means of a locked barrier or security fence. }\end{array}$ \\
\hline Electrical Wires & $\begin{array}{l}\text { All electrical wires associated with a wind energy system, other than } \\
\text { wires necessary to connect the wind turbine to its base and to overhead } \\
\text { collection lines, must be located underground. }\end{array}$ \\
\hline Lighting & $\begin{array}{l}\text { A wind tower and turbine may not be artificially lighted unless such } \\
\text { lighting is required by the Federal Aviation Administration. If lighting is } \\
\text { required, the lighting must comply with FAA minimum requirements } \\
\text { and, whenever possible, be at the lowest intensity allowed, avoid the use } \\
\text { of strobe or other intermittent white lights, and use steady red lights. If } \\
\text { more than one lighting alternative is available, the alternative that } \\
\text { causes the least visual disturbance must be used. }\end{array}$ \\
\hline Equipment & $\begin{array}{l}\text { Any electrical equipment associated with a wind energy system must be } \\
\text { located under the sweep area of a blade assembly. }\end{array}$ \\
\hline $\begin{array}{l}\text { Appearance, Color, } \\
\text { and Finish }\end{array}$ & $\begin{array}{l}\text { The exterior surface of any visible components of a wind energy system } \\
\text { must be a non-reflective, neutral color. Wind towers and turbines in a } \\
\text { wind farm system that are located within } 1 \text { mile of each other must be of } \\
\text { uniform design, including tower type, color, number of blades, and } \\
\text { direction of blade rotation. }\end{array}$ \\
\hline Signs & $\begin{array}{l}\text { No wind turbine, tower building, or other structure associated with a } \\
\text { wind energy system may be used to advertise or promote any product or } \\
\text { service. No word or graphic representation, other than appropriate } \\
\text { warning signs and owner identification, may be placed on a wind } \\
\text { turbine, tower, building, or other structure associated with a wind } \\
\text { energy system so as to be visible from any public road. }\end{array}$ \\
\hline
\end{tabular}




\begin{tabular}{|c|c|}
\hline Permits Required & $\begin{array}{l}\text { Zoning Permit and Conditional Use Permit. Fees are required for both, } \\
\text { including a } \$ 100 \text { processing fee under the conditional use permit for } \\
\text { each large wind system included in the wind farm system. }\end{array}$ \\
\hline $\begin{array}{l}\text { Restoration } \\
\text { Requirement }\end{array}$ & $\begin{array}{l}\text { A large wind system, met tower, or wind farm system that is out of service } \\
\text { for a continuous } 12 \text {-month period will be deemed to have been abandoned } \\
\text { and must be removed within } 3 \text { months of receipt of Notice of Abandonment } \\
\text { unless the Administrator withdraws the notice or within } 6 \text { months of } \\
\text { providing notice of termination of operations. The owner must: } \\
\text { 1) Remove all turbines, above-ground improvements, and outdoor } \\
\text { storage } \\
\text { 2) Remove all foundations, pads, and underground electrical wires and } \\
\text { reclaim the site to a depth of } 4 \text { feet below the surface of the ground } \\
\text { 3) Remove all hazardous material in accordance with federal and state } \\
\text { law }\end{array}$ \\
\hline Signal Interference & $\begin{array}{l}\text { 1) The owner of a large wind energy system, met tower, or wind farm } \\
\text { system must take reasonable steps to prevent and eliminate any } \\
\text { interference with the transmission and reception of electromagnetic } \\
\text { communications, such as microwave, radio, telephone, or television } \\
\text { systems. } \\
\text { 2) A large wind energy system or met tower may not be located within } \\
\text { an emergency communication corridor, which is defined as the area } \\
\text { within } 500 \text { feet of a line connecting a specific pair of communication } \\
\text { towers. (See link to ordinance for specific details.) }\end{array}$ \\
\hline Noise & $\begin{array}{l}\text { 1) The noise generated by the operation of a large wind energy system } \\
\text { may not exceed the ambient noise level by more than } 5 \mathrm{~dB} \text { as measured } \\
\text { at any point on property adjacent to the parcel on which the large wind } \\
\text { energy system is located. The noise level generated by the operation of a } \\
\text { large wind energy system will be determined during the investigation of } \\
\text { a noise complaint by comparing the sound level measured when the } \\
\text { wind generator blades are rotating to the sound level measured when the } \\
\text { wind generator blades are stopped. } \\
\text { 2) Each wind tower must have a placard posted in plain view and easily } \\
\text { readable by a person on the ground. The placard must provide a } \\
\text { telephone number for law enforcement or other county officials to call } \\
\text { for purposes of noise complaint investigation, sound level measurement, } \\
\text { or administration of this ordinance. A person must be reachable through } \\
\text { that telephone number at all times, and the owner must be able to } \\
\text { promptly control the operation of the large wind energy system as } \\
\text { necessary to permit noise complaint investigation and sound level } \\
\text { management. }\end{array}$ \\
\hline Shadow Flicker & $\begin{array}{l}\text { The owner of a large wind system must take such reasonable steps as } \\
\text { are necessary to prevent, mitigate, and eliminate shadow flicker on any } \\
\text { occupied structure on a nonparticipating property. }\end{array}$ \\
\hline Link & $\begin{array}{l}\text { http://www.manitowoccounty.com/Upload/8/Chapter\%2024\%20Curren } \\
\text { t\%20-\%202007-1030.pdf }\end{array}$ \\
\hline
\end{tabular}




\section{Mitchell, Wisconsin}

\begin{tabular}{|c|c|}
\hline $\begin{array}{l}\text { Zoning Areas } \\
\text { Where Turbines are } \\
\text { Allowed }\end{array}$ & No zoning area standards \\
\hline Set Backs & $\begin{array}{l}\text { 1) Inhabited structures: Each wind turbine shall be set back from the } \\
\text { nearest residence, school, hospital, church, or public library a distance } \\
\text { of no less than } 1.1 \text { times its total height. } \\
\text { 2) Property lines: Each wind turbine shall be set back from the nearest } \\
\text { property line a distance of no less than } 1.1 \text { times its total height, unless } \\
\text { appropriate easements are secured from adjacent property owners, or } \\
\text { other acceptable mitigation is approved by the Commission. } \\
\text { 3) Public roads: Each wind turbine shall be set back from the nearest } \\
\text { public road a distance no less than } 1.1 \text { times its total height, determined } \\
\text { at the nearest boundary of the underlying right-of-way for such public } \\
\text { road. } \\
\text { 4) Communication and electrical lines: Each wind turbine shall be set } \\
\text { back from the nearest above-ground public electric power line or } \\
\text { telephone line a distance of no less than } 1.1 \text { times its total height, } \\
\text { determined from the existing power line or telephone line. }\end{array}$ \\
\hline $\begin{array}{l}\text { Spacing and } \\
\text { Density }\end{array}$ & No spacing or density standards \\
\hline Height & No height standard \\
\hline Clearance & $\begin{array}{l}\text { The blade tip of any wind turbine shall, at its lowest point, have ground } \\
\text { clearance of no less than } 2 / 3 \text { the height of the tower to the hub or } 14 \\
\text { feet, whichever is greater. }\end{array}$ \\
\hline Access & $\begin{array}{l}\text { 1) Wind turbine towers shall not be climbable up to } 14 \text { feet above } \\
\text { ground level. } \\
\text { 2) All access doors to wind turbine towers and electrical equipment } \\
\text { shall be lockable. }\end{array}$ \\
\hline Electrical Wires & $\begin{array}{l}\text { 1) All wiring between wind turbines and WECS substations shall be } \\
\text { underground. } \\
\text { 2) Electrical controls and control wiring and power lines shall be } \\
\text { wireless or not above ground except for where wind farm collector } \\
\text { wiring is brought together for connection to the transmission or } \\
\text { distribution network, adjacent to that network. }\end{array}$ \\
\hline Lighting & $\begin{array}{l}\text { WECS shall not be artificially lighted, except to the extent required by } \\
\text { the Federal Aviation Administration or other applicable authority. }\end{array}$ \\
\hline Equipment & No equipment standards \\
\hline $\begin{array}{l}\text { Appearance, Color, } \\
\text { and Finish }\end{array}$ & Wind turbines shall be painted a non-reflective, non-obtrusive color. \\
\hline Signs & $\begin{array}{l}\text { Wind turbines shall not be used to display advertising except for } \\
\text { reasonable identification of the manufacturer or operator of the WECS. } \\
\text { Appropriate warning signage shall be placed on wind turbine towers, } \\
\text { electrical equipment, and WECS entrances. }\end{array}$ \\
\hline Permits Required & Conditional Use Permit Wind Energy Siting Permit \\
\hline
\end{tabular}




\begin{tabular}{|c|c|}
\hline $\begin{array}{l}\text { Restoration } \\
\text { Requirement }\end{array}$ & No decommissioning standards \\
\hline Signal Interference & $\begin{array}{l}\text { The applicant shall minimize or mitigate interference with } \\
\text { electromagnetic communications, such as radio, telephone, microwaves, } \\
\text { or television signals caused by any WECS. }\end{array}$ \\
\hline Noise & 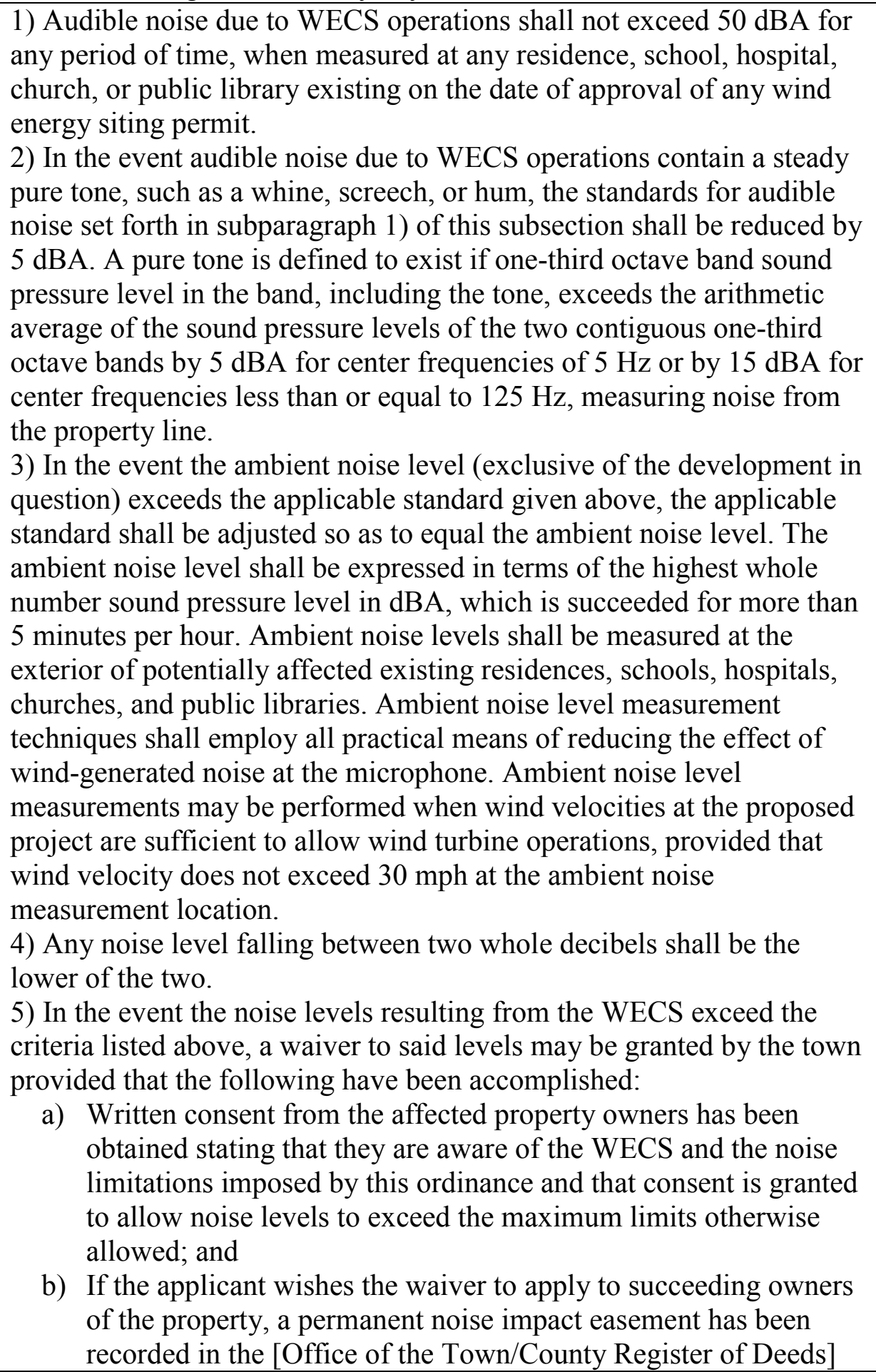 \\
\hline
\end{tabular}




\begin{tabular}{|l|l|}
\hline & \multicolumn{1}{|c|}{$\begin{array}{c}\text { that describes the benefited and burdened properties and that } \\
\text { advises all subsequent owners of the burdened property that noise } \\
\text { levels in excess of those permitted by this ordinance may exist on } \\
\text { or at the burdened property. }\end{array}$} \\
\hline Shadow Flicker & No shadow flicker standards \\
\hline Link & http://www.townofmitchell.com/ordinances/windturbines.pdf \\
\hline
\end{tabular}




\section{Morrison, Wisconsin}

\begin{tabular}{|c|c|}
\hline $\begin{array}{l}\text { Zoning Areas } \\
\text { Where Turbines are } \\
\text { Allowed }\end{array}$ & $\begin{array}{l}\text { Large Wind Energy Conversion Systems may only be constructed in } \\
\text { areas zoned Agriculture. }\end{array}$ \\
\hline Set Backs & $\begin{array}{l}\text { 1) Inhabited structures: Each large wind turbine shall be set back from } \\
\text { the nearest inhabited structure a distance of no less than the greater of } \\
\text { two times its total height or } 1,000 \text { feet. (The Morrison Town Board may } \\
\text { grant a waiver to this requirement for a participating and/or non- } \\
\text { participating landowner to decrease the setback. In no instance shall the } \\
\text { setback be decreased to less than } 1.1 \text { times the total height of the wind } \\
\text { turbine. This waiver shall be signed by the impacted property owner and } \\
\text { recorded with the Brown County Register of Deeds.) } \\
\text { 2) Property lines: Each wind turbine shall be set back from the nearest } \\
\text { property line } 1.1 \text { times its total height. (The Morrison Town Board may } \\
\text { grant a waiver to this provision where strict enforcement would not } \\
\text { serve the public interest. This waiver shall be signed by the impacted } \\
\text { owner and recorded with the Brown County Register of Deeds.) } \\
\text { 3) Public roads: Each wind turbine shall be set back from the nearest } \\
\text { public road right-of-way a distance no less than } 1.1 \text { times its total } \\
\text { height. (The Morrison Town Board may grant a waiver to this provision } \\
\text { where strict enforcement would not serve the public interest.) } \\
\text { 4) Communication and utility lines } \\
\text { a) The owner of WECS must meet all utility company setbacks } \\
\text { and/or easements. The owner of WECS is responsible for } \\
\text { contacting the appropriate utility to determine location of all } \\
\text { above-ground and underground utility lines including, but not } \\
\text { limited to, electricity, natural gas, petroleum, propane, cable } \\
\text { television, and fiber optic. } \\
\text { b) Utility line and/or easement locations shall be provided to the } \\
\text { Town of Morrison for verification. }\end{array}$ \\
\hline $\begin{array}{l}\text { Spacing and } \\
\text { Density }\end{array}$ & No spacing and density standards \\
\hline Height & $\begin{array}{l}\text { No specific height standards, although a large wind turbine is defined to } \\
\text { be up to } 500 \text { feet tall }\end{array}$ \\
\hline Clearance & $\begin{array}{l}\text { The blade tip of any large wind turbine shall, at its lowest point, have } \\
\text { ground clearance of no less than } 75 \text { feet. }\end{array}$ \\
\hline Access & $\begin{array}{l}\text { 1) Wind turbine towers shall not be climbable up to } 15 \text { feet above } \\
\text { ground level and must be located inside of the tower. } \\
\text { 2) All access doors to wind turbine towers and electrical equipment } \\
\text { shall be locked when unattended. } \\
\text { 3) All substations shall be fenced to prevent public access. Chain link } \\
\text { fencing shall include vinyl or aluminum slats or other landscaping to } \\
\text { create an opaque visual barrier. }\end{array}$ \\
\hline Electrical Wires & $\begin{array}{l}\text { 1) All electrical wires and lines connecting each turbine to the next } \\
\text { turbine shall be installed underground. The wires and lines running from } \\
\text { the last turbine in a string to any substation connecting to the electric }\end{array}$ \\
\hline
\end{tabular}




\begin{tabular}{|c|c|}
\hline & $\begin{array}{l}\text { utility shall also be run underground, unless the town determines that } \\
\text { overhead lines would best serve the intent of the ordinance. } \\
\text { 2) Electrical controls, control wiring, and power lines shall be wireless } \\
\text { or not above ground except where wind farm collector wiring is brought } \\
\text { together for connection to the transmission or distribution network, } \\
\text { adjacent to that network. }\end{array}$ \\
\hline Lighting & $\begin{array}{l}\text { WECS shall not be artificially lighted, except to the extent required by } \\
\text { the Federal Aviation Administration. }\end{array}$ \\
\hline Equipment & No equipment standards \\
\hline $\begin{array}{l}\text { Appearance, Color, } \\
\text { and Finish }\end{array}$ & $\begin{array}{l}\text { 1) Wind turbines shall be painted a non-reflective, non-obtrusive color, } \\
\text { such as grey, white, or off-white. } \\
\text { 2) At large WECS sites, the design of the building and related structures } \\
\text { shall, to the extent possible, use materials, colors, textures, screening, } \\
\text { and landscaping that will blend the large WECS into the natural setting } \\
\text { and existing environment. }\end{array}$ \\
\hline Signs & $\begin{array}{l}\text { 1) No form of advertising shall be allowed on the pole, turbine, blades, } \\
\text { or other buildings or facilities associated with the use, except for } \\
\text { reasonable identification of the manufacturer or operator of the large } \\
\text { WECS. } \\
\text { 2) Appropriate warning signage shall be placed on wind turbine towers, } \\
\text { electrical equipment, and large WECS entrances. }\end{array}$ \\
\hline Permits Required & Building Permit, Conditional Use Permit \\
\hline $\begin{array}{l}\text { Restoration } \\
\text { Requirement }\end{array}$ & $\begin{array}{l}\text { 1) The site shall be stabilized, graded, and cleared of any debris by the } \\
\text { owner of the facility or its assigns. If the site is not to be used for } \\
\text { agricultural practices following removal, the site shall be seeded to } \\
\text { prevent soil erosion. } \\
\text { 2) Any foundation shall be removed to a minimum depth of } 8 \text { feet below } \\
\text { grade by the owner of the facility or its assigns. (Following removal, the } \\
\text { location of any remaining wind turbine foundation shall be identified on } \\
\text { a map as such and recorded with the deed to the property with the } \\
\text { Brown County Register of Deeds.) } \\
\text { 3) Any access roads shall be removed, cleared, and graded by the owner } \\
\text { of the large WECS or its assigns, unless the property owner wants to } \\
\text { keep the access road. The Town of Morrison will not be assumed to take } \\
\text { ownership of any access road unless through official action of the town } \\
\text { board. }\end{array}$ \\
\hline Signal Interference & $\begin{array}{l}\text { The applicant shall mitigate any interference with electromagnetic } \\
\text { communications, such as, but not limited to, radio, telephone, or } \\
\text { television signals, including any public agency radio systems, caused by } \\
\text { any large WECS. }\end{array}$ \\
\hline Noise & $\begin{array}{l}\text { 1) Audible noise due to large WECS operations shall not exceed } 50 \\
\text { dBA for } 10 \% \text { of the time over a continuous } 24 \text {-hour period when } \\
\text { measured at any inhibited structure existing on the date of approval of a } \\
\text { large WECS building permit. } \\
\text { a) If audible noise exceeds } 50 \mathrm{dBA} \text { for } 10 \% \text { of the time over a } \\
\text { continuous } 24 \text {-hour period, the offending wind turbine must be }\end{array}$ \\
\hline
\end{tabular}




\begin{tabular}{|c|c|}
\hline & $\begin{array}{l}\text { inoperable until repairs are completed or a waiver is obtained } \\
\text { from affected property owners. } \\
\text { b) The Town of Morrison reserves the right to review the repair plan } \\
\text { and evaluate its effectiveness. } \\
\text { 2) WECS shall not create an audible steady, pure tone such as a whine, } \\
\text { screech, hum, or vibration. } \\
\text { 3) In the event the ambient noise level (exclusive of the development in } \\
\text { question) exceeds the applicable standard given above, the applicable } \\
\text { standard shall be adjusted so as to equal the ambient noise level. The } \\
\text { ambient noise level shall be expressed in terms of the highest whole } \\
\text { number sound pressure level in dBA, which is succeeded for more than } \\
5 \text { minutes per hour. Ambient noise level measurement techniques shall } \\
\text { employ all practical means of reducing the affect of wind-generated } \\
\text { noise at the microphone. Ambient noise level measurements may be } \\
\text { performed when wind velocities at the proposed project site are } \\
\text { sufficient to allow wind turbine operation, provided that the wind } \\
\text { velocity does not exceed } 30 \text { mph at the ambient noise level } \\
\text { measurement location. } \\
\text { 4) Any noise level emanating from WECS falling between two whole } \\
\text { decibels shall be the higher of the two. } \\
\text { 5) The applicant or wind turbine facility owner shall pay for any noise } \\
\text { monitoring or measurements, with need determined by the Morrison } \\
\text { Town Board. } \\
\text { 6) In the event the noise levels resulting from the WECS exceed the } \\
\text { criteria listed above, a waiver to said levels may be granted by the town } \\
\text { providing the following has been accomplished: } \\
\text { a) Written consent from the affected property owners has been } \\
\text { obtained stating that they are aware of the large WECS and noise } \\
\text { limitations imposed by this ordinance and that consent is granted } \\
\text { to allow noise levels to exceed the maximum limits otherwise } \\
\text { allowed; and, } \\
\text { b) A permanent noise impact easement has been recorded in the } \\
\text { Brown County Register of Deeds that describes the benefited and } \\
\text { burdened properties and that advises all subsequent owners of the } \\
\text { burdened property that noise levels in excess of those permitted } \\
\text { by this ordinance may exist on or at the burdened property. }\end{array}$ \\
\hline Shadow Flicker & $\begin{array}{l}\text { The large WECS owner/operator shall make reasonable efforts to } \\
\text { minimize or mitigate shadow flicker to any inhabited structure on a non- } \\
\text { participating landowner's property. }\end{array}$ \\
\hline Link & $\begin{array}{l}\text { http://www.townofmorrison.org/OrdinancesZoning/XXIV_Wind_Energ } \\
\text { y Facility Ordinance final.pdf }\end{array}$ \\
\hline
\end{tabular}


Town of Rockland, Wisconsin

\begin{tabular}{|c|c|}
\hline $\begin{array}{l}\text { Zoning Areas } \\
\text { Where Turbines are } \\
\text { Allowed }\end{array}$ & Exclusive Agriculture \\
\hline Set Backs & 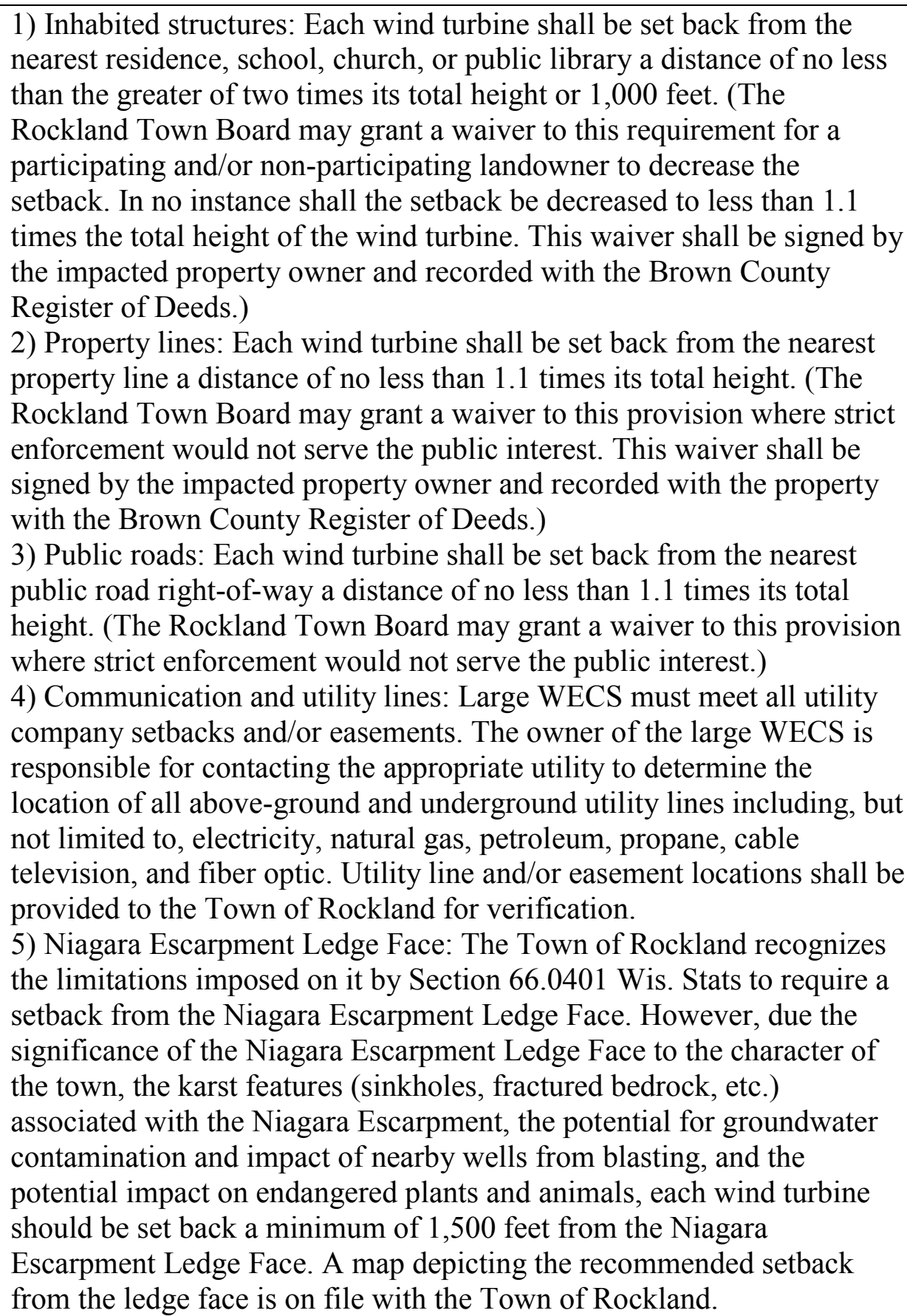 \\
\hline $\begin{array}{l}\text { Spacing and } \\
\text { Density }\end{array}$ & No spacing and density standards \\
\hline Height & 170 feet and over is considered a large wind energy system \\
\hline Clearance & $\begin{array}{l}\text { The blade tip of any wind turbine shall, at its lowest point, have ground } \\
\text { clearance of no less than } 75 \text { feet. }\end{array}$ \\
\hline
\end{tabular}




\begin{tabular}{|c|c|}
\hline Access & $\begin{array}{l}\text { 1) Wind turbine towers shall not be climbable up to } 15 \text { feet above } \\
\text { ground level and must be located inside the tower. } \\
\text { 2) All access doors to wind turbine towers and electrical equipment } \\
\text { shall be lockable. } \\
\text { 3) All substations shall be fenced to prevent public access. Chain link } \\
\text { fencing shall include vinyl or aluminum slats or other landscaping to } \\
\text { create an opaque visual barrier. }\end{array}$ \\
\hline Electrical Wires & $\begin{array}{l}\text { 1) Electrical controls, control wiring, and power lines shall be wireless } \\
\text { or not above ground where wind farm collector wiring is brought } \\
\text { together for connection to the transmission or distribution network, } \\
\text { adjacent to that network. } \\
\text { 2) All electrical components of the large WECS shall conform to } \\
\text { relevant and applicable local, state, and national codes, and relevant and } \\
\text { applicable international standards. } \\
\text { 3) All wiring between wind turbines and the large WECS substations } \\
\text { shall be underground. }\end{array}$ \\
\hline Lighting & $\begin{array}{l}\text { WECS shall not be artificially lighted, except to the extent required by } \\
\text { the Federal Aviation Administration. }\end{array}$ \\
\hline Equipment & No equipment standards \\
\hline $\begin{array}{l}\text { Appearance, Color, } \\
\text { and Finish }\end{array}$ & $\begin{array}{l}\text { 1) Wind turbines shall be painted a non-reflective, non-obtrusive color, } \\
\text { such as grey, white, or off-white. } \\
\text { 2) At large WECS sites, the design of the buildings and related } \\
\text { structures shall, to the extent possible, use materials, colors, textures, } \\
\text { screening, and landscaping that will blend the large WECS into the } \\
\text { natural setting and existing environment. }\end{array}$ \\
\hline Signs & $\begin{array}{l}\text { 1) No form of advertising shall be allowed on the pole, turbine, blades, } \\
\text { or other buildings, except for reasonable identification of the } \\
\text { manufacturer or operator of the large WECS. } \\
\text { 2) Appropriate warning signage shall be placed on wind turbine towers, } \\
\text { electrical equipment, and large WECS entrances. }\end{array}$ \\
\hline Permits Required & Conditional Use Permit \\
\hline $\begin{array}{l}\text { Restoration } \\
\text { Requirement }\end{array}$ & $\begin{array}{l}\text { 1) The site shall be stabilized, graded, and cleared of any debris by the } \\
\text { owner of the facility or its assigns. If the site is not to be used for } \\
\text { agricultural practices following removal, the site shall be seeded to } \\
\text { prevent soil erosion. } \\
\text { 2) Any foundation shall be removed to a minimum depth of } 4 \text { feet below } \\
\text { grade, or to the level of bedrock if less than } 4 \text { feet below grade, by the } \\
\text { owner of the facility or its assigns. (Following removal, the location of } \\
\text { any remaining wind turbine foundation shall be identified on a map as } \\
\text { such and recorded with the deed to the property with the Brown County } \\
\text { Register of Deeds.) } \\
\text { 3) Any access roads shall be removed, cleared, and graded by the owner } \\
\text { of the facility or its assigns, unless the property owner wants to keep the } \\
\text { access road. The Town of Rockland will not be assumed to take } \\
\text { ownership of any access road unless through official action of the town } \\
\text { board. }\end{array}$ \\
\hline
\end{tabular}




\begin{tabular}{|c|c|}
\hline & $\begin{array}{l}\text { 4) Removal shall conform to the contract between property owner and } \\
\text { the owner/operator of the large WECS, in addition to the requirements } \\
\text { set forth in this ordinance. }\end{array}$ \\
\hline Signal Interference & $\begin{array}{l}\text { The applicant shall mitigate any interference with electromagnetic } \\
\text { communications, such as radio, telephone, or television signals, } \\
\text { including any public agency radio systems, caused by any large WECS. }\end{array}$ \\
\hline Noise & 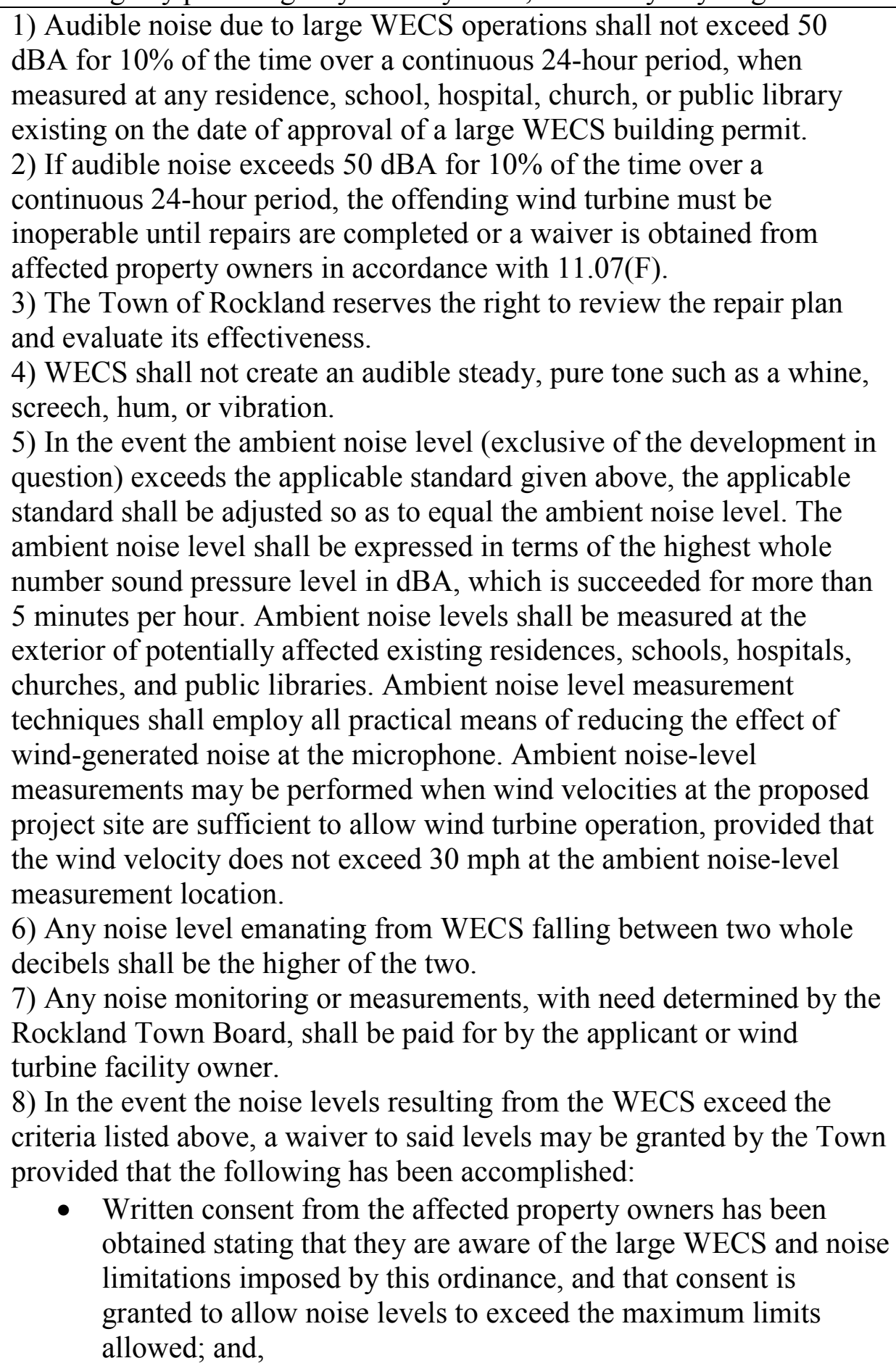 \\
\hline
\end{tabular}




\begin{tabular}{|l|l|}
\hline & $\begin{array}{l}\text { A permanent noise impact easement has been recorded in the } \\
\text { Brown County Register of Deeds that describes the benefited } \\
\text { and burdened properties and that advises all subsequent owners } \\
\text { of the burdened property that noise levels in excess of those } \\
\text { permitted by this ordinance may exist on or at the burdened } \\
\text { property. }\end{array}$ \\
\hline Shadow Flicker & $\begin{array}{l}\text { The large WECS owner and/or operator shall make reasonable efforts to } \\
\text { minimize or mitigate shadow flicker to any occupied building on non- } \\
\text { participating landowner's property. }\end{array}$ \\
\hline Link & $\begin{array}{l}\text { http///www.townofrockland.org/Documents/Large\%20Wind\%20Energy } \\
\text { \%20Facility\%20Ordinance.pdf }\end{array}$ \\
\hline
\end{tabular}




\section{Shawano County, Wisconsin}

\begin{tabular}{|c|c|}
\hline $\begin{array}{l}\text { Zoning Areas } \\
\text { Where Turbines are } \\
\text { Allowed }\end{array}$ & No zone-specific regulations \\
\hline Set Backs & $\begin{array}{l}\text { 1) Structure setbacks: Four times the total height of the WECS from all } \\
\text { sensitive receptors and livestock facilities, but in no case less than } 1,000 \\
\text { feet } \\
\text { 2) Property line setbacks: Two times the total height of the WECS from } \\
\text { all ownership property lines, but in no case less than } 500 \text { feet } \\
\text { 3) Public roads and highway setbacks: Four times the total height of the } \\
\text { WECS from the right-of-way line of any public road or highway, but in } \\
\text { no case less than } 1,000 \text { feet } \\
\text { 4) Railroad setbacks: } 1.5 \text { times the total height of the WECS from all } \\
\text { railroad right-of-ways, but in no case less than } 500 \text { feet } \\
\text { 5) Above-ground transmission lines greater than } 12 \mathrm{kV} \text { setbacks: } 1.5 \\
\text { times the total height of the WECS from the edge of the easement, but } \\
\text { in no case less than } 500 \text { feet } \\
\text { 6) Water bodies setback: Four times the total height of the WECS from } \\
\text { the ordinary high-water mark of the water body, but in no case less than } \\
\text { 1,000 feet } \\
\text { 7) Wetland setbacks: Four times the total height of the WECS from the } \\
\text { delineated boundary of the wetland, but in no case less than } 1,000 \text { feet } \\
\text { 8) Sensitive environmental areas setbacks: WECS shall be located at a } \\
\text { minimum of } 2 \text { miles from Navarino Wildlife Area or other identified } \\
\text { sensitive environmental areas. } \\
\text { 9) Historical, cultural and archeological resource setbacks: Four times } \\
\text { the total height of the WECS from all historical, cultural, and } \\
\text { archeological resources, but in no case less than } 1,000 \text { feet } \\
\text { 10) Scenic setbacks: No WECS shall be located within } 1 \text { mile of any } \\
\text { state, county, village or town park or designated recreation area. }\end{array}$ \\
\hline $\begin{array}{l}\text { Spacing and } \\
\text { Density }\end{array}$ & $\begin{array}{l}\text { Minimum distance between turbines shall be two times the total height } \\
\text { of WECS }\end{array}$ \\
\hline Height & $\begin{array}{l}\text { No height limitations, but WECS greater than } 125 \text { feet in height are } \\
\text { subject to the full extent of the WECS ordinance. }\end{array}$ \\
\hline Clearance & $\begin{array}{l}\text { The blade tip of WECS shall, at the lowest points, have ground } \\
\text { clearance of not less than } 75 \text { feet. }\end{array}$ \\
\hline Access & $\begin{array}{l}\text { 1) WECS shall not be climbable up to } 15 \text { feet above ground level. } \\
\text { 2) All access doors to WECS and electrical equipment shall be lockable } \\
\text { and remain locked at all times when operator personnel are not present. }\end{array}$ \\
\hline Electrical Wires & $\begin{array}{l}\text { 1) All electrical conductors, telecommunications, and fiber optic cables } \\
\text { associated with the WECS shall be underground. } \\
\text { 2) All underground conductors, including neutral conductors, shall be } \\
\text { insulated for the applicable voltage and of the same ampacity. } \\
\text { 3) Underground installations, regardless of voltage, must comply with } \\
\text { all right-of-way requirements and clearances as identified in this } \\
\text { ordinance. }\end{array}$ \\
\hline
\end{tabular}




\begin{tabular}{|c|c|}
\hline & $\begin{array}{l}\text { 4) Rights-of-way width for distances greater than } 100 \text { feet of } \\
\text { underground installation in unpaved areas shall be a minimum of } 30 \text { feet } \\
\text { and a maximum of } 50 \text { feet unless otherwise specifically agreed to by the } \\
\text { property owner. } \\
\text { 5) Rights-of-way width for distances of } 100 \text { feet or less of underground } \\
\text { installation in unpaved areas shall be a minimum of } 20 \text { feet unless } \\
\text { otherwise specifically agreed to by the property owner. } \\
\text { 6) Wherever practical, easements shall be placed immediately adjacent } \\
\text { to the outside edge of road rights-of-way. }\end{array}$ \\
\hline Lighting & $\begin{array}{l}\text { Shall be lit to Federal Aviation Administration minimal standards only. } \\
\text { Where acceptable to the FAA, the Shawano County Planning, } \\
\text { Development, and Zoning Committee will approve red lights over white } \\
\text { lights, and steady lights over strobed or intermittent lights. Lighting } \\
\text { shall be shielded from ground view to FAA maximum standards. Area } \\
\text { and security lighting shall not exceed } 175 \text { watts and } 25 \text { feet height and } \\
\text { shall be shielded from neighboring sensitive receptors. }\end{array}$ \\
\hline Equipment & No equipment standards \\
\hline $\begin{array}{l}\text { Appearance, Color, } \\
\text { and Finish }\end{array}$ & $\begin{array}{l}\text { 1) Wind energy conversion units shall be painted a non-obtrusive color } \\
\text { (e.g., light environmental color such as white, grey, or beige). } \\
\text { 2) The design of WECS buildings and related structures shall, to the } \\
\text { extent reasonably possible, use materials; colors, textures, screening, } \\
\text { and landscaping that will blend the facility into the natural setting and } \\
\text { the existing environment. }\end{array}$ \\
\hline Signs & $\begin{array}{l}\text { No advertising sign or logo shall be placed or painted on any WECS. A } \\
\text { WECS Conditional Use Permit may allow the placement of no more } \\
\text { than two advertising signs relating to the development of the project } \\
\text { site, but no sign shall exceed } 15 \text { square feet in surface area or } 8 \text { feet in } \\
\text { height. }\end{array}$ \\
\hline Permits Required & Conditional Use Permit \\
\hline $\begin{array}{l}\text { Restoration } \\
\text { Requirement }\end{array}$ & $\begin{array}{l}\text { The owner/operator shall remove all equipment associated with the } \\
\text { WECS and restore the site to its original condition at the end of the } \\
\text { permit or when any WECS are deemed inoperable or unsafe. The } \\
\text { restoration shall include removal of all materials above and below } \\
\text { ground; road repair, if any; and all re-grading and re-vegetation } \\
\text { necessary to return the subject property to the condition existing prior to } \\
\text { establishment of WECS. The restoration shall reflect the site-specific } \\
\text { character including topography, vegetation, drainage, and any unique } \\
\text { environmental features and shall be completed within } 1 \text { year. The } \\
\text { owner/operator shall incur all costs associated with implementing the } \\
\text { removal and site restoration plan. }\end{array}$ \\
\hline Signal Interference & $\begin{array}{l}\text { WECS shall be sited and operated so that they do not interfere with } \\
\text { television, telephone (including cellular and digital), microwave, } \\
\text { satellite (dish), navigational, or radio reception to neighboring areas. } \\
\text { The applicant and/or operator of the facility shall be responsible for the } \\
\text { full cost of any remediation necessary to provide equivalent alternate } \\
\text { service or correct any problems, including relocation or removal of the }\end{array}$ \\
\hline
\end{tabular}




\begin{tabular}{|l|l|}
\hline & facility, caused or exacerbated by the operation of such equipment and \\
any and all related transmission lines, transformers, and other \\
components related thereto. The owner/operator of the WECS shall \\
respond within 5 business days to any request for a communications \\
interference investigation by a property owner within the project \\
boundary and a 3-mile radius beyond the project boundary. Testing shall \\
commence within 10 working days of the request. The owner/operator is \\
responsible for mitigating within 10 working days from determination \\
of interference cause attributed to the operation of the WECS.
\end{tabular}




\begin{tabular}{|l|l|}
\hline & dB(A) for center frequencies less than or equal to $125 \mathrm{~Hz}$. \\
& 7) Repetitive, impulsive sound penalty: In the event the audible noise \\
due to wind turbine operations contains repetitive, impulsive sounds, the \\
standards for audible noise shall be reduced by $5 \mathrm{~dB}(\mathrm{~A})$. \\
8) Pure tone and repetitive, impulsive tone penalty: In the event the \\
audible noise due to wind turbine operations contains both a pure tone \\
and repetitive impulsive sounds, the standards for audible noise shall be \\
reduced by a total of 5 dB(A). \\
9) Operations - low-frequency noise: WECS that emit impulsive sound \\
below 20 Hz that adversely affects the habitability or use of any existing \\
dwelling unit, hospital, school, library, nursing home, or other sensitive \\
noise receptor shall be deemed unsafe and must be shut down \\
immediately.
\end{tabular}


Utah

Lehi City, Utah

\begin{tabular}{|c|c|}
\hline $\begin{array}{l}\text { Zoning Areas } \\
\text { Where Turbines are } \\
\text { Allowed }\end{array}$ & $\begin{array}{l}\text { May only be allowed in a Wind Energy Overlay Zone. } \\
\text { 1) Overlay Zones may be created only in Industrial and Technical } \\
\text { Manufacturing Zones. } \\
\text { 2) No Wind Overlay Zone may be initially created without specific } \\
\text { requests for WECS. Requests for a Wind Energy Overlay Zone shall be } \\
\text { submitted concurrently with an application for Concept Plan for a Wind } \\
\text { Energy Conversion System. } \\
\text { 3) All other uses listed as permitted or conditional uses in the } \\
\text { underlying zoning district of the overlay zone may be allowed subject to } \\
\text { the applicable permitted or conditional use approval processes. } \\
\text { 4) Once a Wind Overlay Zone has been created, new wind energy } \\
\text { structures or facilities may be allowed in that zone as a Conditional Use. }\end{array}$ \\
\hline Set Backs & $\begin{array}{l}\text { 1) Residential zone or public use: Each wind turbine shall be set back } \\
\text { from the nearest residential zoning district (including any zone that } \\
\text { allows for residential uses) school, church, public park, or public library } \\
\text { a distance of } 1,000 \text { feet. } \\
\text { 2) Property lines: Each wind turbine shall be set back from the nearest } \\
\text { property line a distance of no less than } 1.1 \text { times its total height, unless } \\
\text { appropriate easements are secured from adjacent property owners or } \\
\text { other acceptable mitigation is approved by the planning commission. } \\
\text { 3) Public roads: Each wind turbine shall be set back a distance of no less } \\
\text { than } 1.1 \text { times its total height determined at the nearest boundary of the } \\
\text { underlying right-of-way for such public road. } \\
\text { 4) Communication and electrical lines: Each wind turbine shall be set } \\
\text { back from the nearest above-ground public electric power line or } \\
\text { telephone line a distance of no less than } 1.1 \text { times its total height, } \\
\text { determined from the existing power line or telephone line. } \\
\text { 5) Wetlands: Each wind turbine shall be set back } 500 \text { feet from any } \\
\text { wetlands as delineated by the U.S. Army Corp of Engineers. This } \\
\text { distance may be adjusted to be greater or lesser at the discretion of the } \\
\text { reviewing body, based on topography, land cover, land uses, and other } \\
\text { factors that influence the flight patterns of resident birds. }\end{array}$ \\
\hline $\begin{array}{l}\text { Spacing and } \\
\text { Density }\end{array}$ & No more than one turbine per acre will be allowed. \\
\hline Height & The total height for a wind turbine shall not exceed 250 feet. \\
\hline Clearance & $\begin{array}{l}\text { The minimum distance between the ground and any part of the rotor or } \\
\text { blade system shall be } 20 \text { feet. }\end{array}$ \\
\hline Access & $\begin{array}{l}\text { 1) Wind turbine towers shall not be climbable up to } 12 \text { feet above } \\
\text { ground level. } \\
\text { 2) All access doors to wind turbine towers and electrical equipment } \\
\text { shall be lockable. } \\
\text { 3) A 6-foot high fence with a locking gate shall be required to enclose } \\
\text { each tower or group of towers unless otherwise requested by applicant } \\
\text { and approved by the planning commission as part of the Conditional }\end{array}$ \\
\hline
\end{tabular}




\begin{tabular}{|c|c|}
\hline & $\begin{array}{l}\text { Use Permit. The color and type of fencing for each WECS installation } \\
\text { shall be determined on the basis of individual applications as safety } \\
\text { needs dictate. }\end{array}$ \\
\hline Electrical Wires & $\begin{array}{l}\text { Electrical controls and control wiring and power lines shall be wireless } \\
\text { or not above ground except where WECS collector wiring is brought } \\
\text { together for connection to the transmission or distribution network, } \\
\text { adjacent to that network. }\end{array}$ \\
\hline Lighting & $\begin{array}{l}\text { WECS shall not be artificially lighted, except to the extent required by } \\
\text { the Federal Aviation Administration or other applicable authority. }\end{array}$ \\
\hline Equipment & No equipment standards \\
\hline $\begin{array}{l}\text { Appearance, Color, } \\
\text { and Finish }\end{array}$ & $\begin{array}{l}\text { 1) The design of WECS, including any buildings or related structures, shall } \\
\text { to the extent reasonably possible use materials, colors, textures, screening, } \\
\text { and landscaping that will help reduce the visual impact of the WECS. } \\
\text { 2) WECS shall not project above the top of ridgelines. For the purposes } \\
\text { of this section, ridgelines shall consist of prominent ridgelines that are } \\
\text { highly visible from any major roadway classified as collector or greater } \\
\text { in intensity. A ridgeline shall also include the crest of any ridgeline and } \\
\text { the land located within } 100 \text { feet horizontally on either side of the crest. } \\
\text { 3) Individual WECS within a wind overlay zone shall be constructed } \\
\text { using wind turbines whose appearance, with respect to one another, is } \\
\text { similar within and throughout the zone to provide reasonable uniformity } \\
\text { in overall size, geometry, and rotational speeds. } \\
\text { 4) All wind turbines and other structures shall be finished in a single, } \\
\text { non-reflective matte finished color or camouflage scheme. }\end{array}$ \\
\hline Signs & $\begin{array}{l}\text { 1) No advertising signs are allowed on any part of the WECS, including } \\
\text { fencing, support structures, and wind turbines except for reasonable } \\
\text { identification of the manufacturer or operator of the WECS. No } \\
\text { lettering, company insignia, advertising, or graphics shall be on any part } \\
\text { of the tower, hub, or blades. } \\
\text { 2) Appropriate warning signs shall be placed on wind turbine towers, } \\
\text { electrical equipment, and WECS entrances. Signage shall include } \\
\text { emergency contact information. }\end{array}$ \\
\hline Permit & Conditional Use permit \\
\hline $\begin{array}{l}\text { Restoration } \\
\text { Requirement }\end{array}$ & $\begin{array}{l}\text { The manner in which the WECS will be decommissioned and the site } \\
\text { restored shall include removal of all structures and debris to a depth of } 3 \\
\text { feet, restoration of the soil, and restoration of the vegetation (consistent } \\
\text { and compatible with surrounding vegetation). }\end{array}$ \\
\hline Signal Interference & $\begin{array}{l}\text { The applicant shall minimize or mitigate any interference with } \\
\text { electromagnetic communications, such as radio, telephone, or television } \\
\text { signals caused by any WECS. }\end{array}$ \\
\hline Noise & $\begin{array}{l}\text { Audible noise due to WECS operations shall not exceed } 55 \mathrm{dBA} \text { for any } \\
\text { period of time measured at the WECS site's property line. }\end{array}$ \\
\hline Shadow Flicker & No shadow flicker standards \\
\hline Link & http://www.lehi-ut.gov/planning/files/devcode/Ch19WindEnergyFacility.pdf \\
\hline Other & $\begin{array}{l}\text { Minimal parcel size: WECS must be located on a parcel that is at least } \\
10 \text { acres in size and } 1 \text { additional acre per wind turbine. }\end{array}$ \\
\hline
\end{tabular}




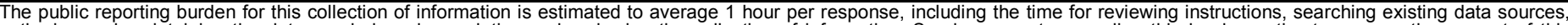

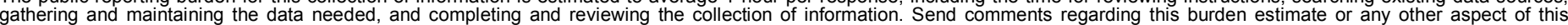

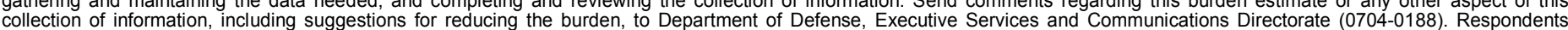

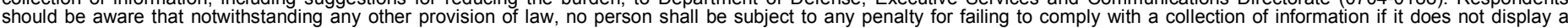

should be aware that notwithstandin

PLEASE DO NOT RETURN YOUR FORM TO THE ABOVE ORGANIZATION.

\begin{tabular}{l|l|l|l} 
1. REPORT DATE $(D D-M M-Y Y Y Y)$ & 2. & REPORT TYPE & 3. DATES COVERED (FrOm - TO)
\end{tabular}

December 2008

Technical Report

4. TITLE AND SUBTITLE
Overview of Existing Wind Energy Ordinances

5a. CONTRACT NUMBER

DE-AC36-08-GO28308

5b. GRANT NUMBER

5c. PROGRAM ELEMENT NUMBER

6. AUTHOR(S)

F. Oteri

5d. PROJECT NUMBER

NREL/TP-500-44439

5e. TASK NUMBER

WER9.8503

5f. WORK UNIT NUMBER
7. PERFORMING ORGANIZATION NAME(S) AND ADDRESS(ES)

National Renewable Energy Laboratory

1617 Cole Blvd.

Golden, CO 80401-3393
8. PERFORMING ORGANIZATION

REPORT NUMBER

NREL/TP-500-44439

9. SPONSORING/MONITORING AGENCY NAME(S) AND ADDRESS(ES)

10. SPONSOR/MONITOR'S ACRONYM(S) NREL

11. SPONSORING/MONITORING AGENCY REPORT NUMBER

12. DISTRIBUTION AVAILABILITY STATEMENT

National Technical Information Service

U.S. Department of Commerce

5285 Port Royal Road

Springfield, VA 22161

13. SUPPLEMENTARY NOTES

14. ABSTRACT (Maximum 200 Words)

Due to increased energy demand in the United States, rural communities with limited or no experience with wind energy now have the opportunity to become involved in this industry. Communities with good wind resources may be approached by entities with plans to develop the resource.Although these opportunities can create new revenue in the form of construction jobs and land lease payments, they also create a new responsibility on the part of local governments to ensure that ordinances will be established to aid the development of safe facilities that will be embraced by the community. The purpose of this report is to educate and engage state and local governments, as well as policymakers, about existing large wind energy ordinances. These groups will have a collection of examples to utilize when they attempt to draft a new large wind energy ordinance in a town or county without existing ordinances.

15. SUBJECT TERMS

wind energy; wind turbines; wind energy ordinances; model ordinances; existing ordinances; wind regulations; wind policies; shadow flicker; turbine finish; clearance; noise standards; permits; set backs; signal interference standards; zoning; spacing and density

16. SECURITY CLASSIFICATION OF:

\begin{tabular}{l|l|l|}
\hline a. REPORT & b. ABSTRACT & c. THIS PAGE
\end{tabular}

Unclassified Unclassified Unclassified

\begin{tabular}{|c|c|}
\hline $\begin{array}{l}\text { 17. LIMITATION } \\
\text { OF ABSTRACT }\end{array}$ & $\begin{array}{l}\text { 18. } \\
\text { NUMBER } \\
\text { OF PAGES }\end{array}$ \\
\hline UL & \\
\hline
\end{tabular}

19a. NAME OF RESPONSIBLE PERSON

19b. TELEPHONE NUMBER (Include area code) 